\title{
Susceptibility Status of Aedes aegypti to Insecticides in Colombia
}

\author{
Ronald Maestre Serrano \\ Doctoral Student in Tropical Medicine \\ Cartagena University \\ Colombia
}

\section{Introduction}

Dengue is a disease of public health interest for Colombia due to its impact on morbidity and mortality. This disease mantains an endemic behavior in the departments of the country located below 2200 meters above sea level. Between the years 1978 to 2010 it was recorded approximately a number of 1,011,852 cases of dengue in Colombia. Vector populations of Aedes aegypti in the country have been continuously pressed for over five decades with insecticides, being the most widely used tool for interrupting transmission of dengue virus during outbreaks and epidemics in the absence of an available vaccine (Figure 1). The selection pressure excercised with these chemicals has led to the emergence of resistant populations of the vector to organochlorine, organophosphate, pyrethroid and carbamatelike molecules.

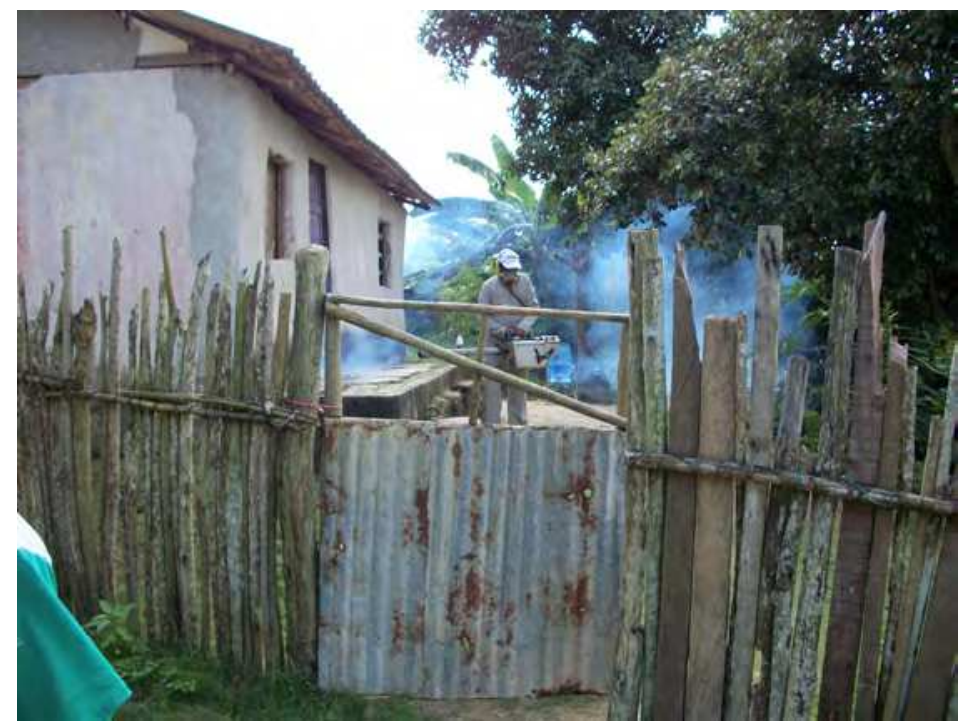

Fig. 1. Application of insecticides in the home by fogging durin outbreaks or epidemics. 
The records of vector resistance in the country have increased considerably since 2007 when in Colombia was created the national network for the surveillance of susceptibility to insecticides used in public health to A. aegypti and major vector of malaria. With this information a base line has been defined for some Colombian departments in the region and basic knowledge has been generated for decision making from the operating standpoint of vector control programs. However, more research on issues related to the enzymatic mechanisms and molecular causes of resistance in vector populations is required as most results to date have been from diagnostic doses through standardized techniques by the Centers for Disease Control and Prevention (CDC) and World Health Organization (WHO). In this chapter these results are socialized and we discuss some ideas related to the topic.

\section{Study area}

The continental territory of the Republic of Colombia is located in the northwest corner of South America on the equator. Colombia is located in the north to $12^{\circ} 26^{\prime} 46^{\prime \prime}$ north latitude at the place called Punta Gallinas in the peninsula of Guajira. To the south, is located at $4^{\circ} 12^{\prime}$ $30^{\prime \prime}$ de latitude south, the East is located at 60 $50^{\prime} 54^{\prime \prime}$ west longitude from Greenwich, by the West is located at $79^{\circ} 02^{\prime} 33^{\prime \prime}$ west longitude from Greenwich.

Colombia territory also includes the archipelago of San Andres and Providencia in the Caribbean sea between $12^{\circ}$ and $16^{\circ} 30^{\prime}$ north latitude and $78^{\circ}$ and $82^{\circ}$ west longitude of Greenwich. Colombia has a land area of $1.141 .748 \mathrm{~km}^{2}$ ranking fourth among the countries of South America.

Colombia is a country with a wide variety of climates, from the coldest to $0^{\circ} \mathrm{C}$ to temperatures exceeding $28^{\circ} \mathrm{C}$ especially in the Caribbean regions, Pacific, Amazon and the Orinoco, accounting for nearly $80 \%$ of Colombia territory. Colombia is divided administratively into 32 states, these in turn are divided into 1102 municipalities.

\section{The situation of dengue in Colombia}

In Colombia, dengue is a disease of public health interest for its impact on morbidity and mortality. Its endemic behavior is due to endemic multiple factors including the re-emergence and intense viral transmission with a rising trend, the behavior of epidemic cycles getting shorter, the increased frequency of outbreaks and serious of the disease, the simultaneous circulation of the four serotypes, infestation by A. aegypti in over $90 \%$ of the national territory located below the 2,200 meters, and other social factors such as uncontrolled increase and lack of basic sanitation in urban centers (Escobar, 2009). The epidemiological pattern of disease in the last decades has been upward, characterized by exponential increase in endemic areas during the different decades. Cyclical behavior has been characterized by epidemic peaks every three or four years, dealing with the reentry of new serotypes to the country.

In Colombia from 1978 to 2010, has officially been recorded a total of 1.011 .852 cases of dengue. For this time period there is record history of the following epidemics in the country:

1977: First recorded epidemic of dengue in Colombia.

2002: Epidemic in 76,996 cases, of which 5269 corresponded to Dengue hemorrhagic fever. 2007: Epidemic in 43,227 cases, of which 4665 corresponded to Dengue hemorrhagic fever. 2010: It is recorded in the country the worst epidemic of this disease with 157,152 confirmed cases and 217 deaths.

The departments that have historically had more transmission of dengue in the country are: Atlántico, Santander, Norte de Santander, Valle del Cauca, Antioquia, Tolima, Huila, Cundinamarca, and Casanare. 


\section{Resistance to insecticides}

\subsection{Definition}

Resistance is defined as the development of the ability to tolerate doses of toxics, which can be lethal to most individuals in a normal population of the same species and is the result of positive selection pressure exerted by the insecticidal over genes initially in low frequency (WHO, 1957).

\subsection{Mechanisms of resistance}

The two main resistance mechanisms are alterations in the target site and metabolic resistance, also called increase in the rate of detoxification of insecticides. However, there are other less frequent as there are the resistance behavior and decreased penetration. (Miller, 1988; Bisset, 2002; Fonseca and Quiñones, 2005)

\subsubsection{Altered target site}

This is generated when no silent mutations occur in structural genes that generate a disturbance of amino acids responsible of anchor of the insecticide at a specific site.

\subsubsection{GABA Receptor}

In bugs this is an hetero multi numeric channel acting as a site of action for cyclodiene and avermectins. The resistance is given by $R d l$ gene (Resistance to dieldrin), which encodes for RDL, a GABA receptor subunit. This type of resistance was first identified in Drosophila first identified this type of resistance (Fonseca and Quiñones, 2005).

\subsubsection{Voltage-gated sodium channel}

They are the target of action of pyrethroids and DDT. The sodium para-channel protein is a complex of over 2000 amino acids, composed of 4 homologous domains separated by hydrophilic links, each domain contains six segments. The first mutation in the sodium channel that conferred resistance was detected in Musca domestica. subsequently mutations in other insects have been identified including Culicidae resistant to pyrethroids (Martínez et al, 1998; Brengues et al, 2003; Anstead, 2005; Saavedra et al, 2007; Brooke, 2008; Chang et al 2009; Yanola et al, 2010).

\subsubsection{Insensitive acethylcholinesterase}

Insecticide resistance, attributed to Ache insensitivity is found in a number of Anopheles and Culex species. In general, this mechanism produces a broad spectrum resistance to most organophosphates and carbamates, although more pronounced to carbamatos. (Bisset, 2002).

\subsubsection{Metabolic resistance}

It is conferred by an increase in detoxification insecticide or an inability to metabolize the toxic compound. The most important form of metabolic resistance is given by detoxificating enzymes of the type glutathione S-transferase, mixed function oxidases and esterases (Bisset 2002).

\subsubsection{Carboxylesterases}

They Catalyze the hydrolysis of carboxylic esters and changes in their expression levels, this is the resistance mechanism that occurs most often in insects. In mosquitoes, high levels of these enzymes have been associated with resistance to organophosphate and pyrethroid insecticides (Cui et al, 2007; Rodriguez et al, 2007). Esterases is a family of six proteins 
Esterases are a family of six proteins grouped in a and $\beta$ hydrolases superfamily. In the Diptera these enzymes are encoded by a gene cluster on the same chromosome, each gene may suffer modification that confers resistance to the insecticide (Fonseca and Quiñones, 2005; Santacoloma, 2008).

\subsubsection{P450 Enzymes or mixed function oxidases}

P450 enzymes are encoded by cytochrome P450 genes. P450 enzymes also have other names such as: cytochrome P450 monooxygenases, mixed function oxidases, monooxygenases with polisustrato, microsomal oxidases and heme-thiolate proteins. In insects these enzymes are involved in growth and development through the processing of fatty acids, hormones and pheromones; in the metabolism of secondary plants products and synthetic chemicals such as insecticides. The cytochrome P-450 is implicated as the major factor in many cases of metabolic resistance to carbamates and detoxify organophosphates, pyrethroids and DDT as well. It expresses in tissues of the gut, fat, reproductive tract and Malpighian tubes (Feyereisen, 1999; Poupardin et al, 2008).

\subsubsection{Glutatione s-transferase}

The glutathione s-transferases (GSTs, EC 2.5.1.18) are phase II enzymes involved in xenobiotics detoxification in many organisms. These enzymes metabolize a wide range of toxic hydrophobic compounds such as drugs, insecticides and endogenous toxic substrates, catalyzing the conjugation of glutathione to the hydrophilic center of toxic substances, allowing the increase in compounds solubility. The GSTs are divided into three main groups: the cytosolic, microsomal and mitochondrial. The mitochondrial GSTs have not been found in insects species including mosquitoes. The cytosolic GSTs in insects are grouped into six different kinds: Delta, Epsilon, Omega, Sigma, Theta and Zeta. Most GSTs involved in the metabolism of xenobiotics in insects belong to the class Delta Epsilon. GSTs in insects have been implicated in the insecticide resistance through its direct metabolism, sequestration or protection against secondary toxic effects such as increased lipid peroxidation induced by exposure to insecticides. Glutathione S- transferase mediated detoxification has been reported for insecticides of the organophosphate type and DDT. The main role of GSTs in the resistance to organophosphates is the detoxification of the insecticide by a conjugation reaction. The specific GSTs also catalyze the metabolism of DDT to a non-toxic substance: 1,1-dichloro-2,2-bis-(p-chlorophenyl) ethane (DDE), through the process of dehydrochlorination. Epsilon class of GST has been involved in resistance to DDT in Anopheles gambiae and A. aegypti (Lumjuan et al, 2007).

\subsection{Type of resistance}

\subsubsection{Cross resistance}

It occurs when a single gene confers resistance to a number of chemicals in the same group, as it is the case of phosphotriesterases that provides resistance to several organophosphates or $k d r$ gene that confers resistance DDT and the pyrethroids (WHO, 1957).

\subsubsection{Multiple resistance}

It occurs when two or more resistance mechanisms are operating in the same insect. The multiple resistance term does not necessarily involve the term cross-resistance, because a bug may be resistant to 2 or more insecticides and each resistance can be attributed to different mechanisms (Bisset, 2002). 


\subsection{Techniques used to detect resistance insecticides in mosquitoes}

\subsubsection{Biological test of the World Health Organization (WHO)}

Technique standardized by the World Health Organization (WHO). In adult mosquitoes the technique consists of exposing individuals of the populations we intent to evaluate to papers impregnated with a single and specific dose of an insecticide during a determined time ( 1 hour with the exception of the organophosphate fenitrothion, to which will be exposed for 2 hours). The mosquitoes are then transfered to a paper that hasn't been impregnated, where they rest under controlled conditions of temperature, relative humidity and an energy source consisting of a sugar solution (Figure 2A). The mortality reading is done after 24 hours of exposure to the insecticide (WHO 1981a).

The susceptibility of larvae is measured by exposing individuals to a diagnostic concentration or several temephos concentrations to determine the lethal concentration ( $\mathrm{LC}_{50}$ or $\mathrm{CL}_{95}$ ) to calculate resistance factor using water as solvent (Figure $2 \mathrm{~B}$ ). Individuals remain exposed for 24 hours. (WHO 1981b) (Santacoloma, 2008).

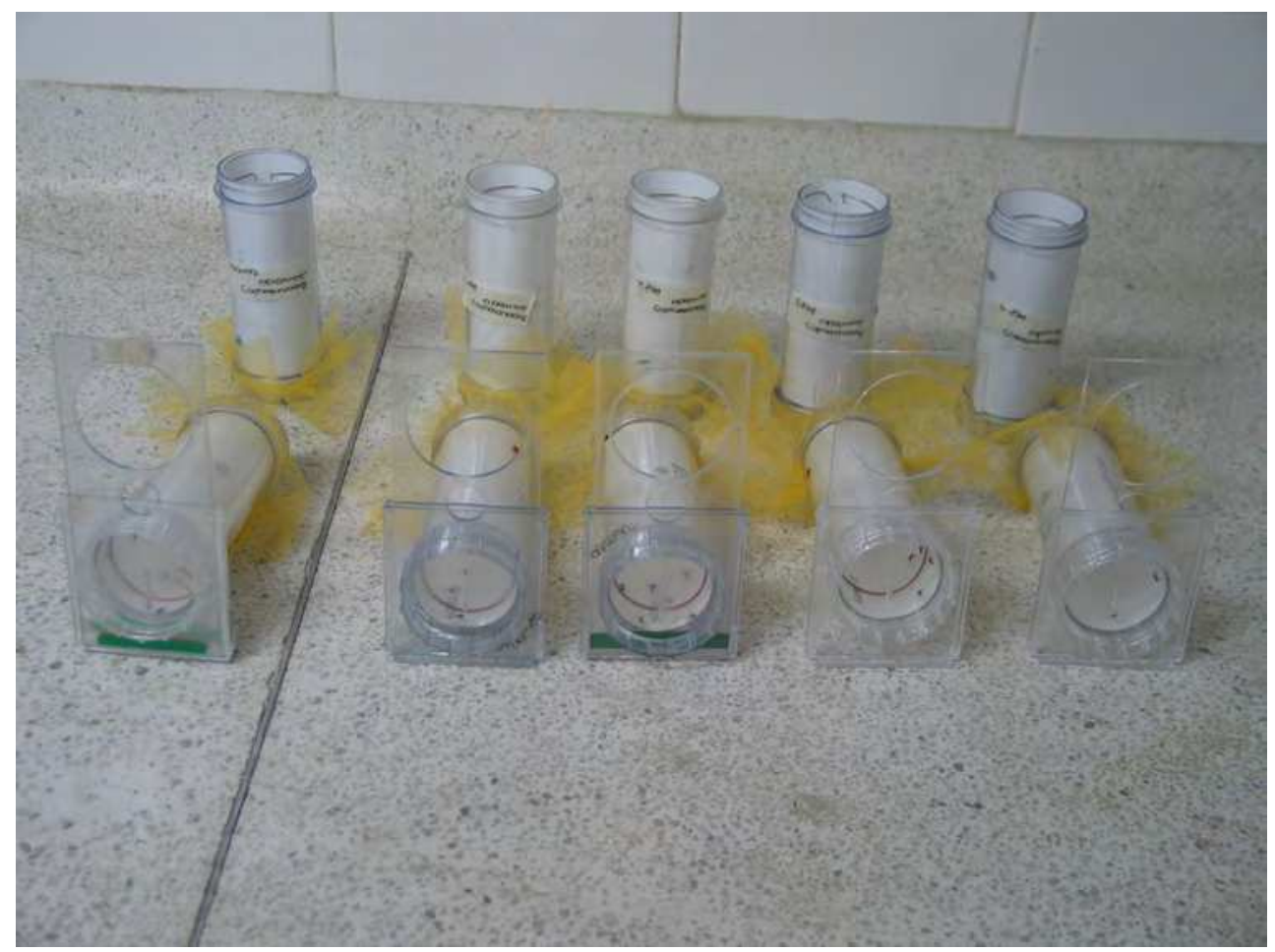

Fig. 2A. Biological test of the World Health Organization (WHO) (mosquitoes).

\subsubsection{Test for biological control center and prevention (CDC)}

The impregnated bottles technique was standardized by the Center for Diseases Control and Prevention (CDC) (Brogdon and McAllister, 1998). The objective of this technique is to measure the time it takes dose of an insecticide to reach the target site of action in the 


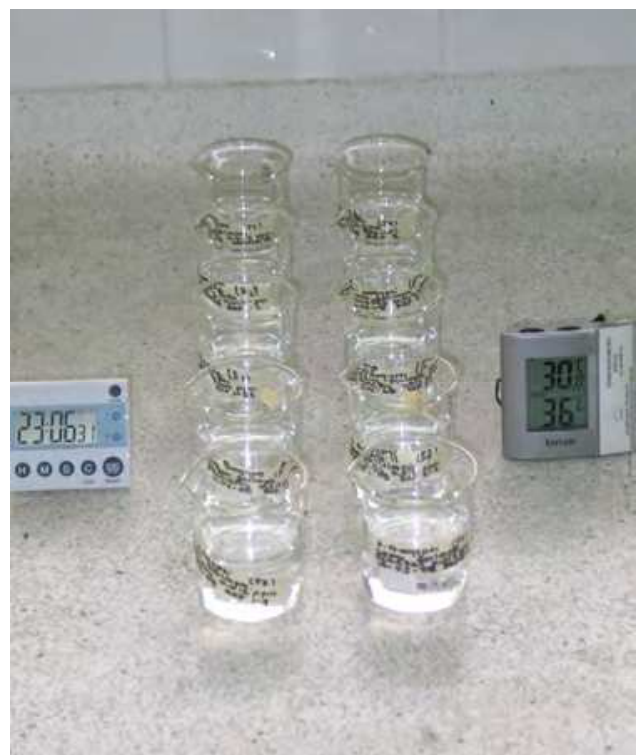

Fig. 2B. Biological test of the World Health Organization (WHO) (Larvae).

mosquito. Involves subjecting a sample of mosquitoes between 15 and 25 individuals of the population to be evaluated on a glass surface pre-impregnated with the dose of insecticide. (Santacoloma, 2008) (Figure 3).

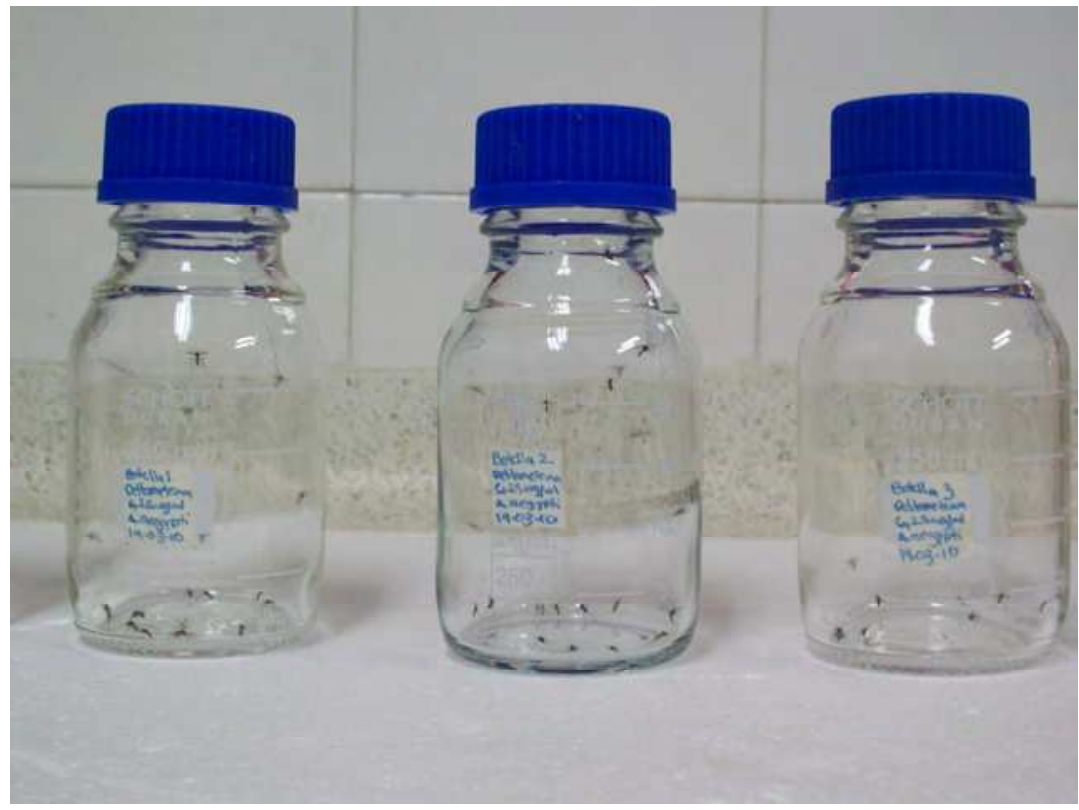

Fig. 3. Test for biological control center and prevention (CDC). 


\subsubsection{Synergists}

These are chemicals that specifically inhibit insecticide-metabolizing enzymes, enhancing their action. Among the synergists more used to detect resistance mechanisms in Insects are the S, S, S - tributilfosforotioato (DJF) and esterases inhibitor and of the enzyme glutathione transferase (GST), the triphenyl phosphate (TFF) specific esterase inhibitor, piperonyl butoxide (PB), an inhibitor of monooxygenases, and ethacrynic acid (EA), a specific inhibitor of the enzyme glutathione transferase (GST) (Rodríguez, 2008).

\subsubsection{Biochemical test}

The biochemical assays are used to define metabolic mechanisms that may be responsible for the physiological resistance in an insect population (WHO, 1992). The metabolic mechanisms include tests to determine the target enzyme decreased sensitivity or the increased enzyme activity. For the first mechanism in particular, measures the change in acetylcholinesterase associated with resistance to carbamates and organophosphates. For the second, evaluates the increased activity of esterases, mixed function oxidases and glutathione s-transferase for kidnapping or increased detoxification of insecticides (Santacoloma, 2008).

\subsubsection{Molecular tests}

These tests consist in the amplification of specific gene sequences through polymerase chain reaction technique $(\mathrm{PCR})$ to detect mutations.

\subsection{Current state of susceptibility to insecticides Aedes aegypti in Colombia}

Since the late forties, when first reported resistance to DDT in Aedes tritaeniorhynchus (Weidemann) and Aedes solicitans (Walker) resistance has been recorded in over a hundred species for one or more insecticides of public health use worldwide (Brown, 1986; Fonseca \& Quiñones, 2005). For A. aegypti in America resistance has been reported to organochlorines, organophosphates, pyrethroids and carbamates in Argentina, Brazil, Mexico, El Salvador, Peru, Panamá, Venezuela, Cuba, Puerto Rico, among other Caribbean countries, whose resistance mechanism in some of these stocks has been associated with altered levels of alpha esters, beta esterases, mixed function oxidases, glutathione s- transferase, as well as mutations in the voltage-gated sodium channel. (Rawlins, 1998; Bisset et al, 2001; Brengues et al, 2003; Macoris et al, 2003; Aparecida et al, 2004; Rodríguez et al, 2004; Chavez et al; 2005, Flores et al, 2005; Pereira da-Cunha et al, 2005, Alvarez et al, 2006, Pereira-Lima et al, 2006; Beserra et al, 2007; Saavedra et al, 2007; Bisset et al, 2009; Martins et al, 2009; AlbrieuLlinas et al, 2010; Polson et al, 2010).

Colombia has applied insecticides for control of vector insects for over five decades. The DDT was the first applied to control malaria and during the campaign for the eradication of A. aegypti conducted in the early 1950. This insecticide was banned in the late 60's, due to the findings of resistance worldwide (Brown, 1986). Since 1970, organophosphates including temephos were applied and from the early 90 's the use of pyrethroids was started. From that time on, the country has been rotating the application of molecules for mosquito control such as: deltamethrin, lambda-cyhalothrin, malathion, fenitrothion and in the last three years cyfluthrin and pirimiphos-methyl. However, the resistance to these insecticides has been documented gradually, making it difficult to take control actions within programs of Vector Borne Diseases in different regions of the country. 
In Colombia until the 1990's there were few works assessing the state of susceptibility in Culicidae populations of interest in public health. Between 1959 and 1987 the first cases of DDT resistance were registered in populations of Anopheles albimanus (Wiedemann) in the municipalities of El Carmen (Bolivar); Codazzi, Robles and Valledupar (Cesar); Acandí (Choco) and An. darlingi (Root) in some locations of Quibdó municipality (Chocó) (Quiñones et al, 1987). Later Suarez et al, (1996) recorded in the 90's decade the first case of resistance to temephos in the A. aegypti species in Cali, Valle del Cauca, and Bisset et al, (1998) evaluated the susceptibility in a strain of Culex quinquefasciatus (Say) from Medellin, Antioquia, encountering resistance to organophosphates malathion, primifos-methyl, chlorpyrifos, temephos, fenthion and pyrethroids deltamethrin and permethrin.

In the absence of enough studies in Colombia on susceptibility status of populations of $A$. aegypti to several insecticides of use in public health and in compliance with public policies enshrined in the American continent resolutions CD39.R11 1996, CD43R4 2001 of the Pan American Health Organization, during the years of 2005 and 2007 a national project was conducted, this was funded by Colciencias (Colombian Science and Research Organization) and implemented by the Learning and Control of Tropical Diseases Program (PECET) of the University of Antioquia, the International Centre for Training and Medical Research (CIDEIM), the National University in Colombia, the National Institute of Health (NIH) and 12 departments of health seeking to generate baseline susceptibility of vector populations in Colombia. This multicentered project gave rise to the national surveillance network susceptibility to insecticides for $A$. aegypti and main vectors of malaria led by the National Institute of Health (INS). Since then the record of resistance to A. aegypti in Colombia expanded through biological tests by the CDC and WHO as well as the determination of impairment of enzymes involved in resistance.

With these results it has been observed for Colombia widespread resistance to DDT (Figure 4A-4B) and variability in susceptibility to the following insecticides: temephos, lambdacyhalothrin, deltamethrin, permethrin, cyfluthrin, etofenprox, malathion, fenitrothion, pirimiphos methyl, bendiocarb and propoxur in different regions, with deterioration in some populations in the levels of nonspecific esterases, mixed function oxidases and in smaller proportion to glutathione s-transferesas (Figure 5A, 5B, 5C, 5D) (Rojas et al, 2003; Cadavid et al, 2008; Fonseca et al, 2006; Fonseca et al, 2007; Orjuela et al; 2007, Salazar et al, 2007; Santacoloma et al, 2008; Fonseca et al, 2009; Maestre et al, 2009; Maestre et al, 2010; Ardila and Brochero, 2010, Gomez et al, 2010; Maestre et al, 2010, Fonseca et al, 2011).

For temephos resistance has been observed in Cundinamarca, Guaviare, Meta, Santander, Cauca, Valle del Cauca, Nariño, Huila, Caldas, Sucre, Atlantico, La Guajira. (Anaya et al, 2007; Santacoloma, 2008; Maestre et al, 2009; Ocampo et al, 2011) (Figure 6).

Pyrethroids that despite being used in Colombia more recently compared to organophosphates, have shown higher levels of resistance despite the increased use time of organophosphate (Figures 7A, 7B, 7C, 7D, 7E), (8A, 8B, 8C). Among the pyrethroids lambda is the insecticide wich displays higher frequency of resistance in vector populations in the country. However, there are pyrethroids such as permethrin and etofenprox that despite having no use in public health have resistance generated in populations of A. aegypti from Casanare, Antioquia, Chocó and Putumayo (Ardila and Brochero, 2010; Fonseca et al, 2011). For the carbamate propoxur discordance in susceptibility results was observed between the WHO technique in which resistance and CDC susceptibility is recorded. Further studies are required to determine the state of populations' susceptibility to the insecticide (Fig. 9 AB). Furthermore, few studies in the country have evaluated the susceptibility of the vector to the 
insecticide Bendiocarb to which there has been resistance registered in the populations in the department of Cauca, Valle del Cauca, Huila and Nariño (Figure 10 AB) (Ocampo et al, 2011). Currently it has not been registered for the country mutations in voltage-gated sodium channel gene. It is therefore recommended studies to perform studies to explain resistance observed to most of the pyrethroids evaluated in different country populations and may be related to a crossed resistance to DDT. It is also recommended to perform studies to determine cross resistance to other molecules such as organophosphate and carbamate, as well as multi resistance studies.

For Colombia it is recommended to maintain a system of permanent time and space surveillance that allows health authorities to use insecticides with technical criteria to maintain effective control interventions in vector populations.

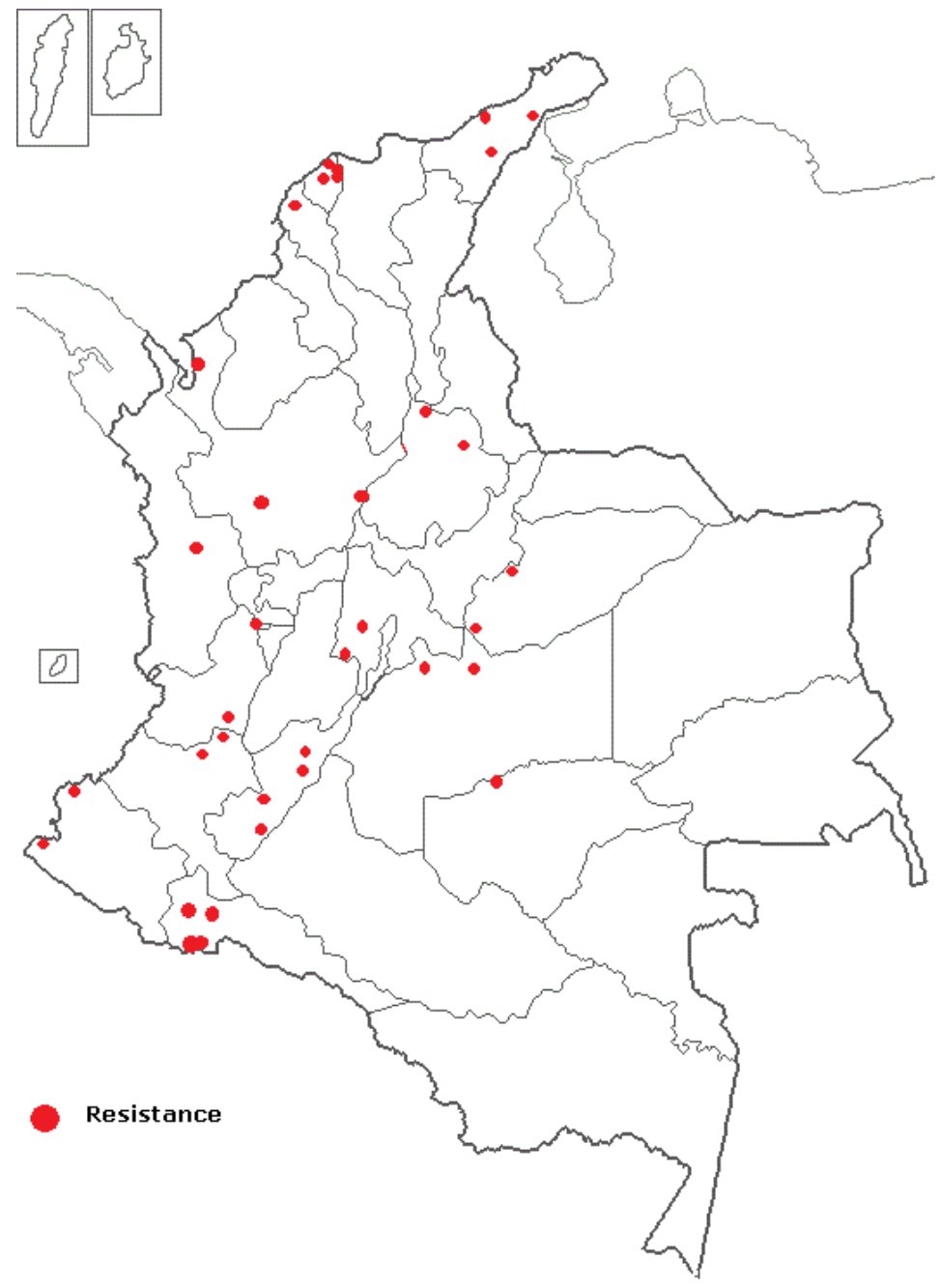

Fig. 4A. Susceptility status of Aedes aegypti populations to DDT in Colombia (CDC test). 


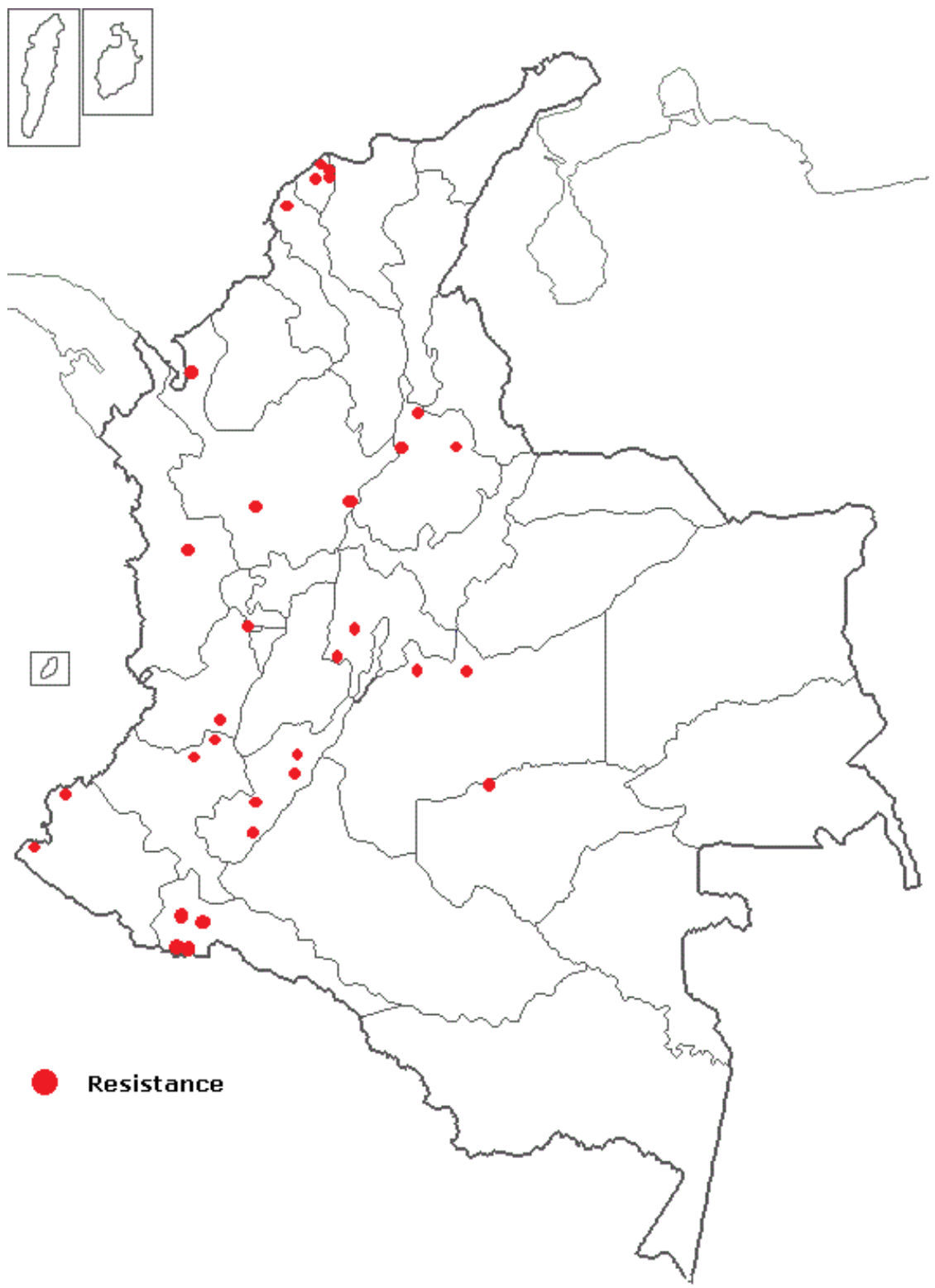

Fig. 4B. Susceptility status of Aedes aegypti populations to DDT in Colombia (OMS test). 


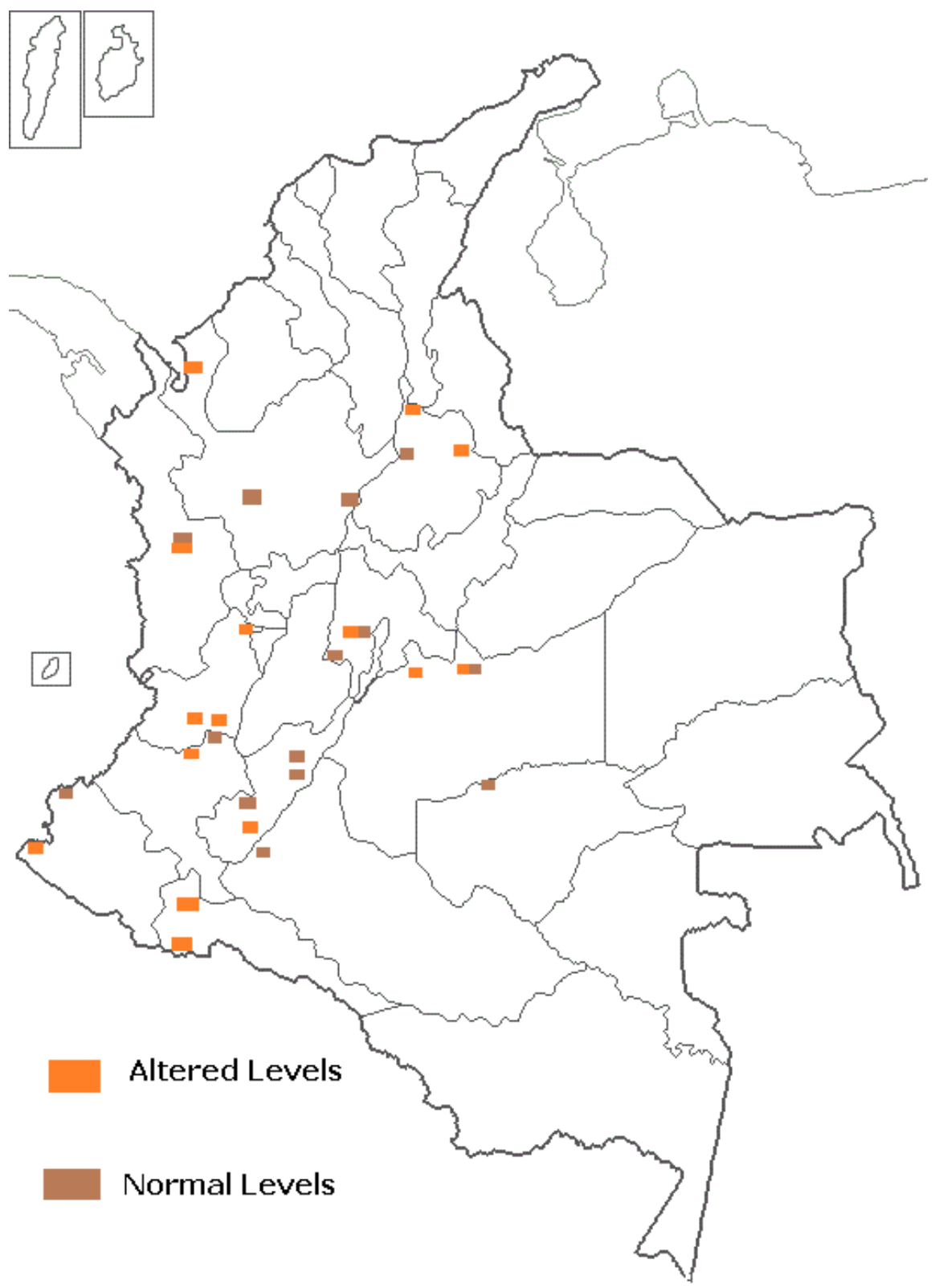

Fig. 5A. Non-specific esterases (NSE). 


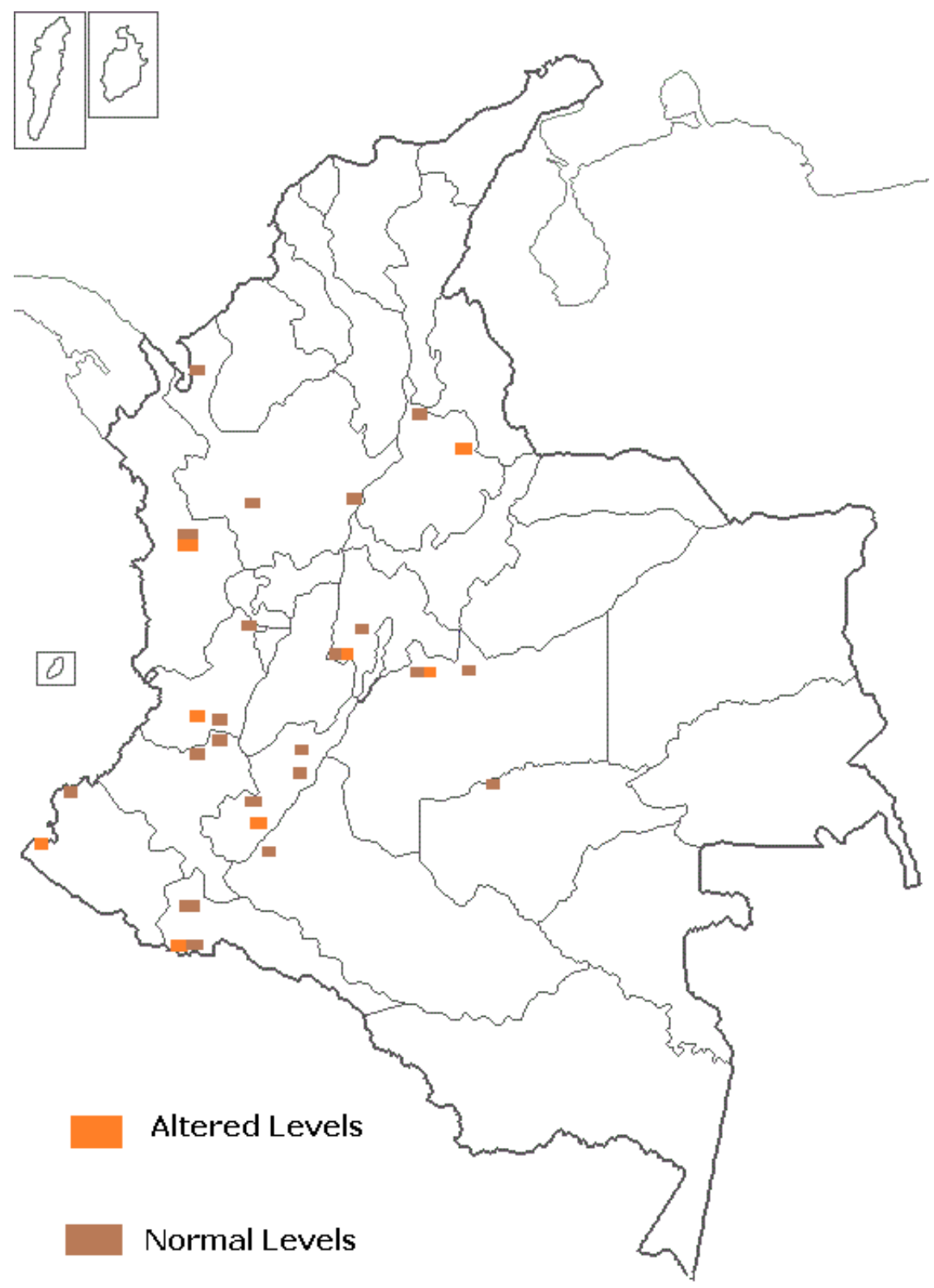

Fig. 5B. Mixed-function oxidases (MFO). 


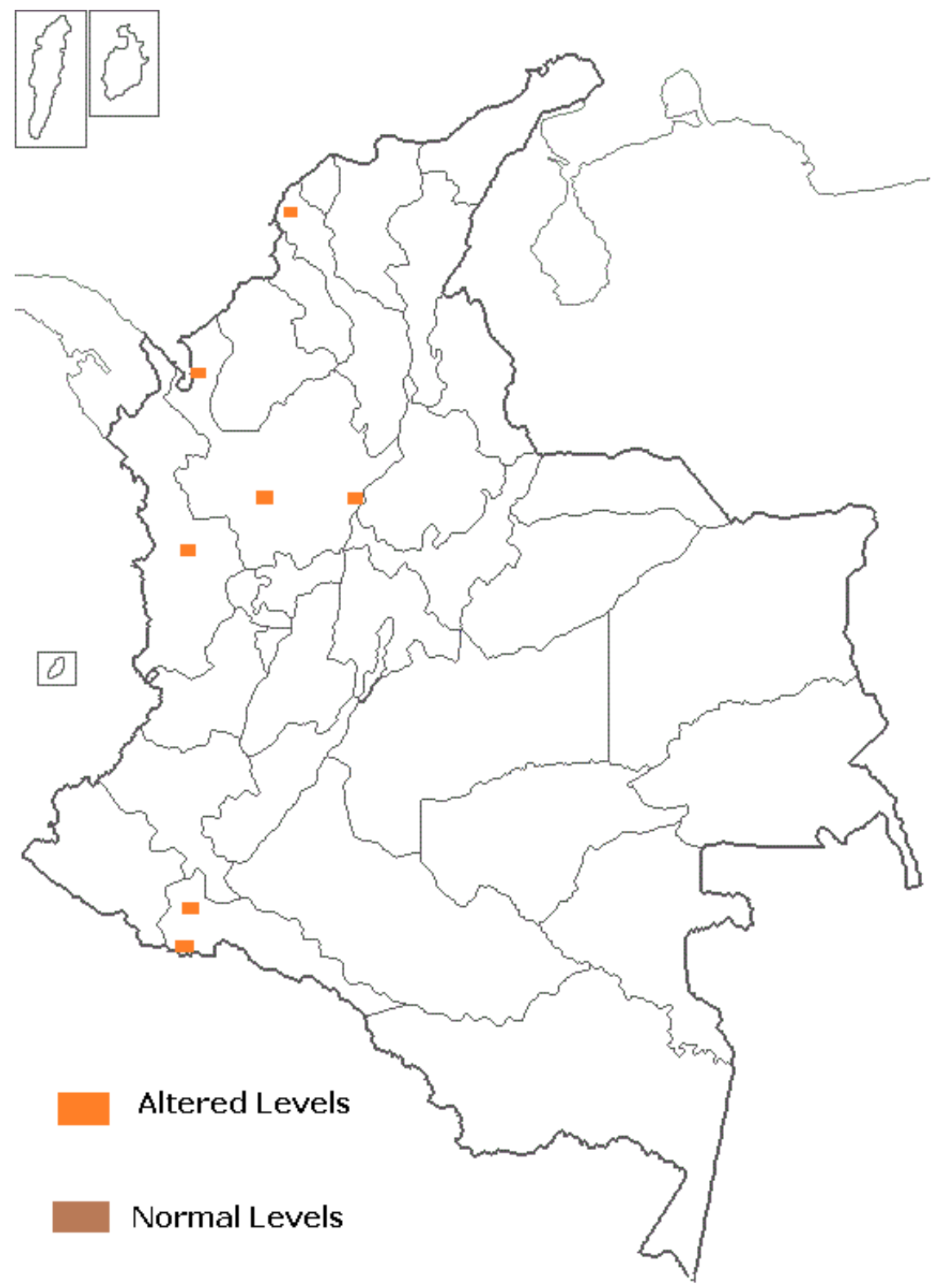

Fig. 5C. Glutathione-S-transferases (GST). 


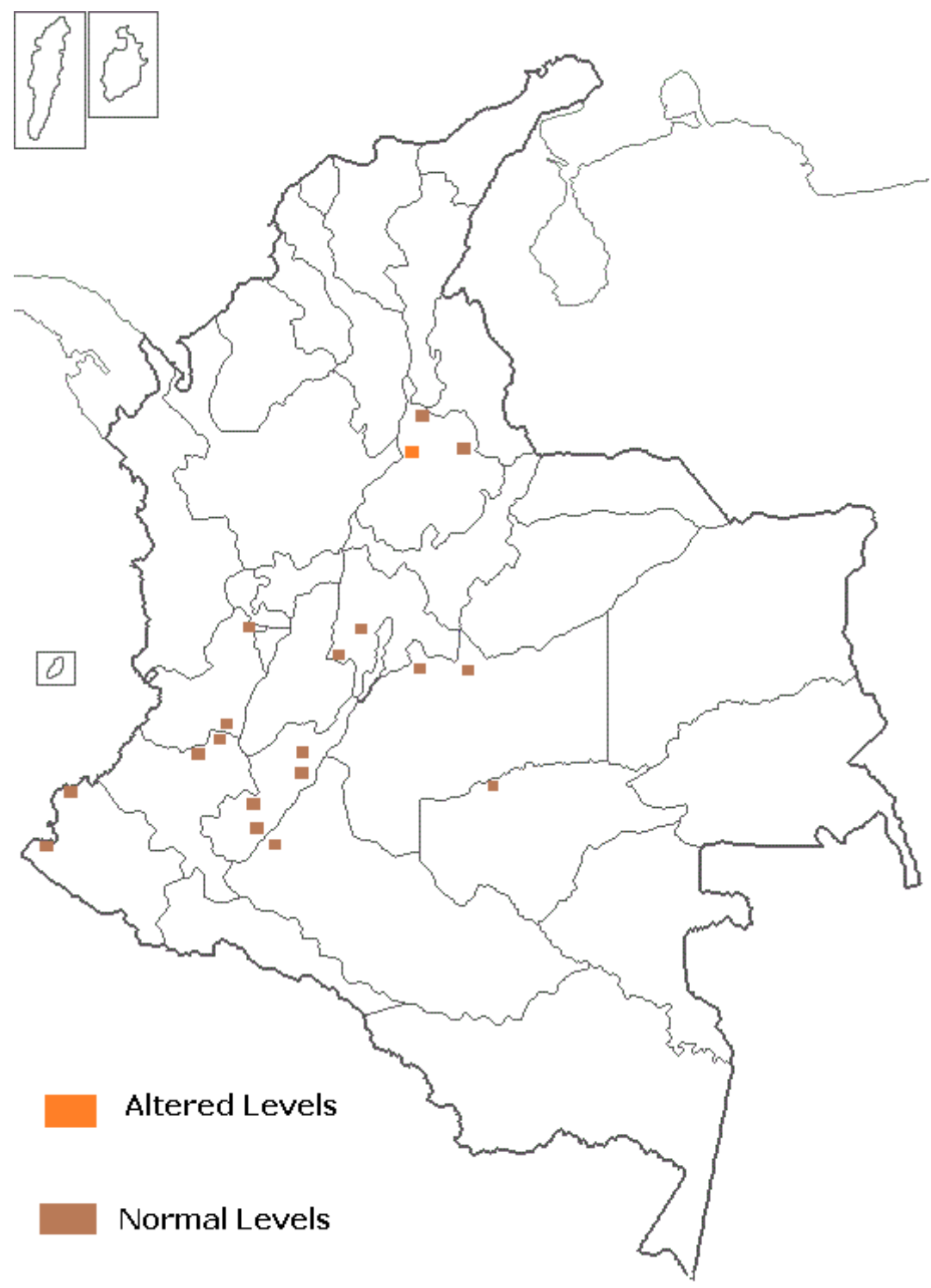

$5 \mathrm{D}$

Fig. 5. Biochemical mechanism of resistance in population of Aedes aegypti in Colombia: Non-specific esterases (NSE) (5A); Mixed-function oxidases (MFO) (5B); Glutathione-Stransferases (GST) (5C); acethylcholinesterase (AChE) (5D). 


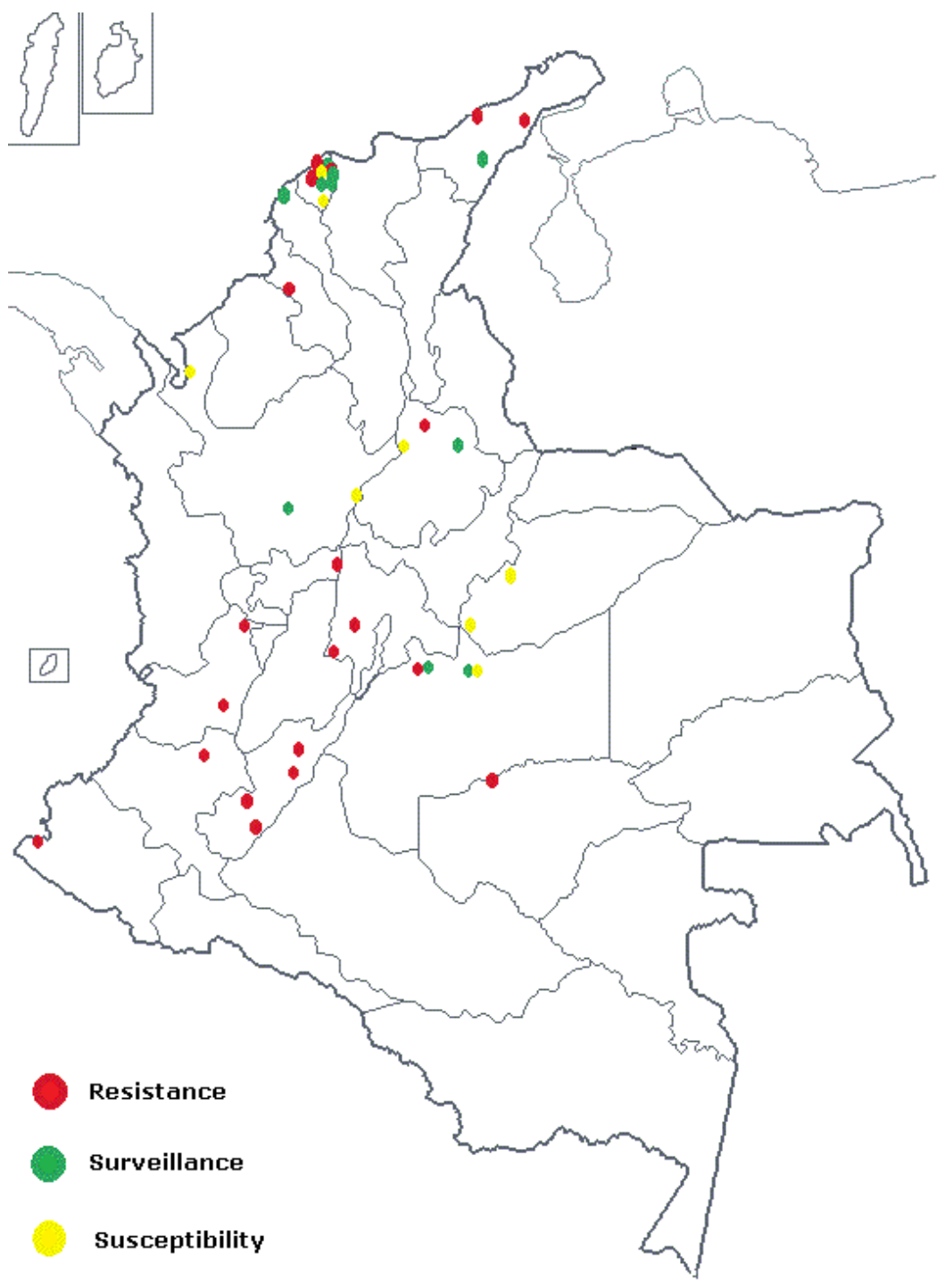

Fig. 6. Susceptility status of Aedes aegypti populations to Temephos in Colombia (OMS test). 


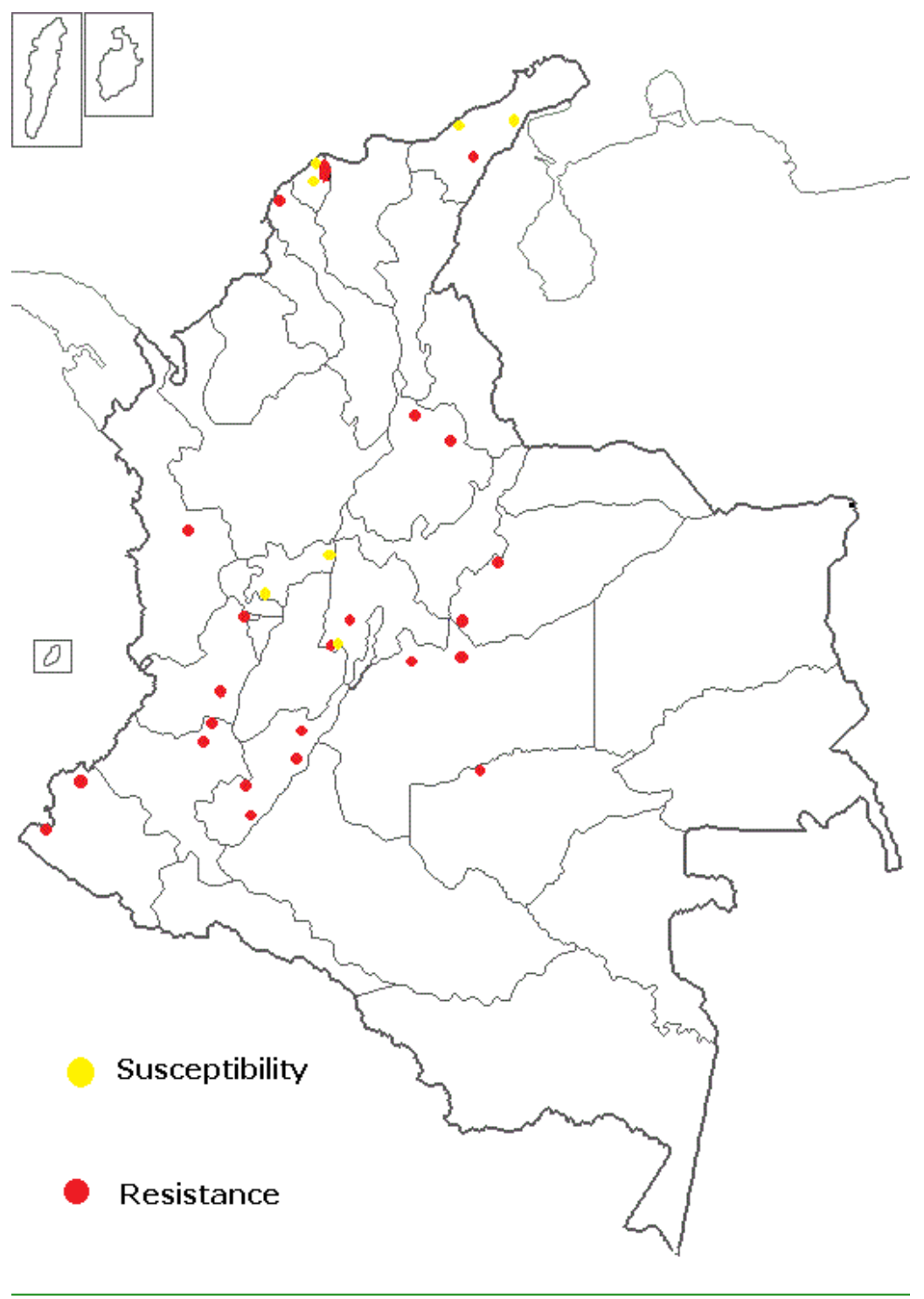

Fig. 7A. Susceptility status of Aedes aegypti populations to lambda-cyhalothrin in Colombia (CDC test). 


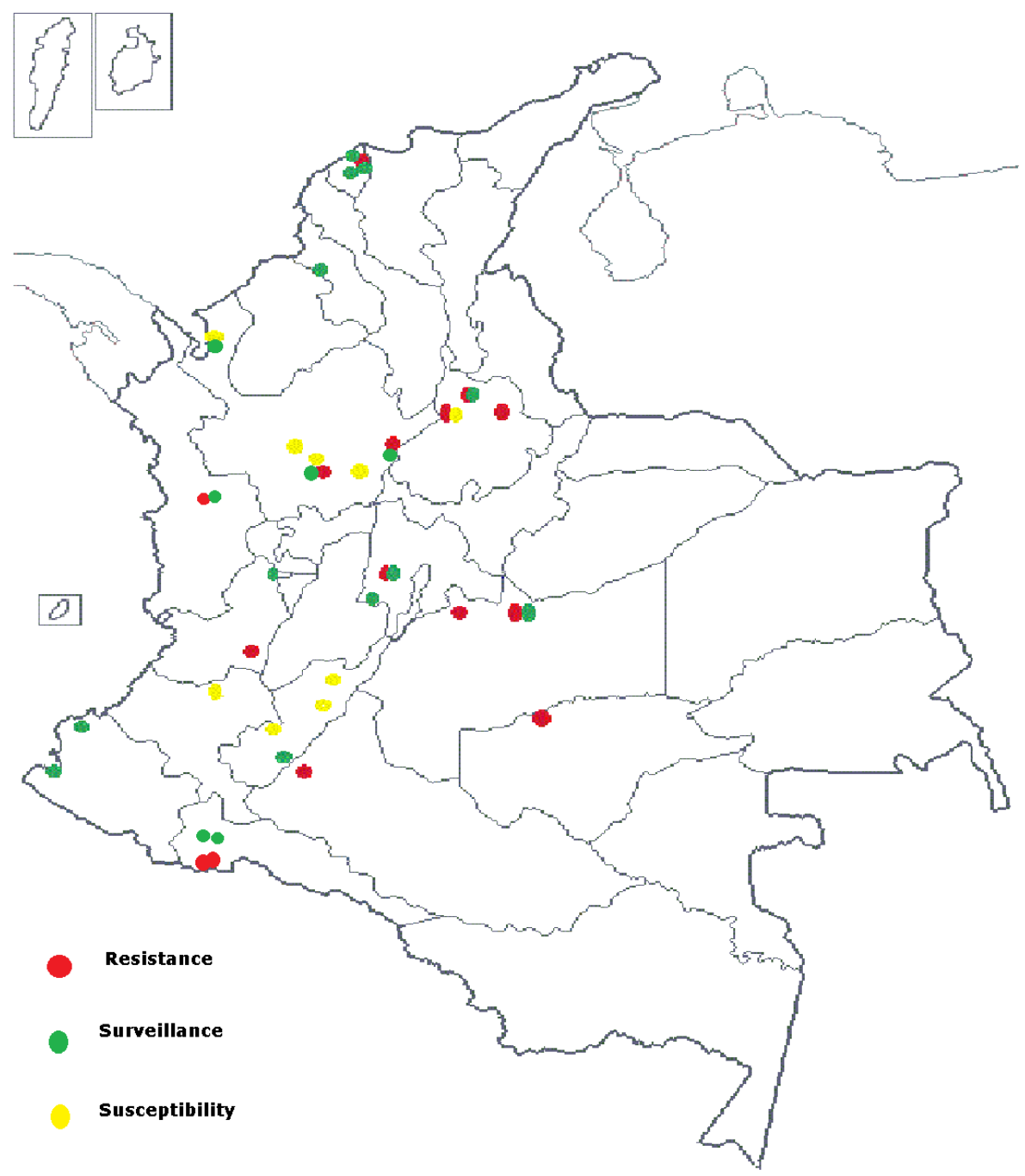

Fig. 7B. Susceptility status of Aedes aegypti populations to lambda-cyhalothrin in Colombia (OMS test). 


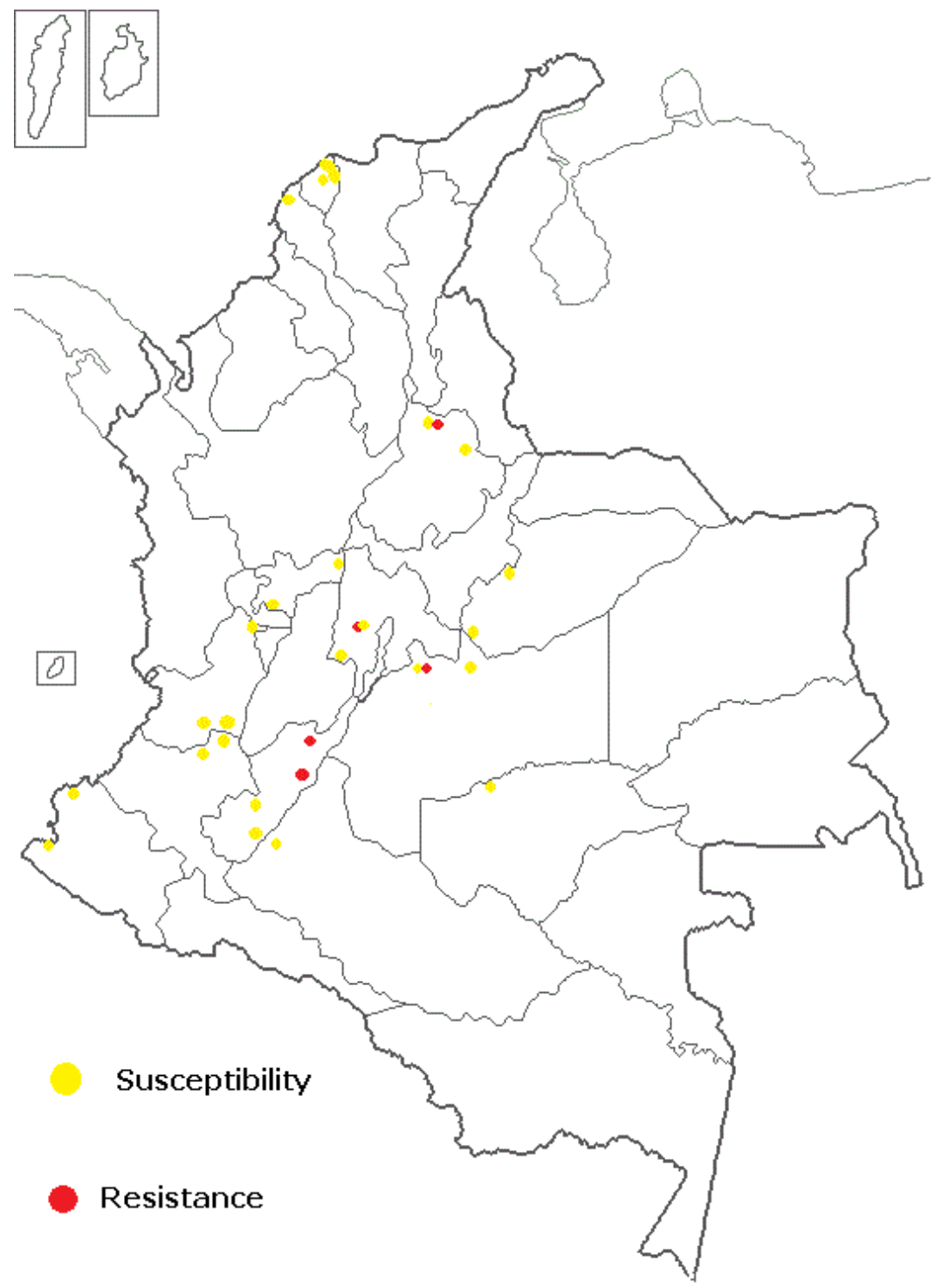

Fig. 7C. Susceptility status of Aedes aegypti populations to Deltamethrin in Colombia (CDC test). 


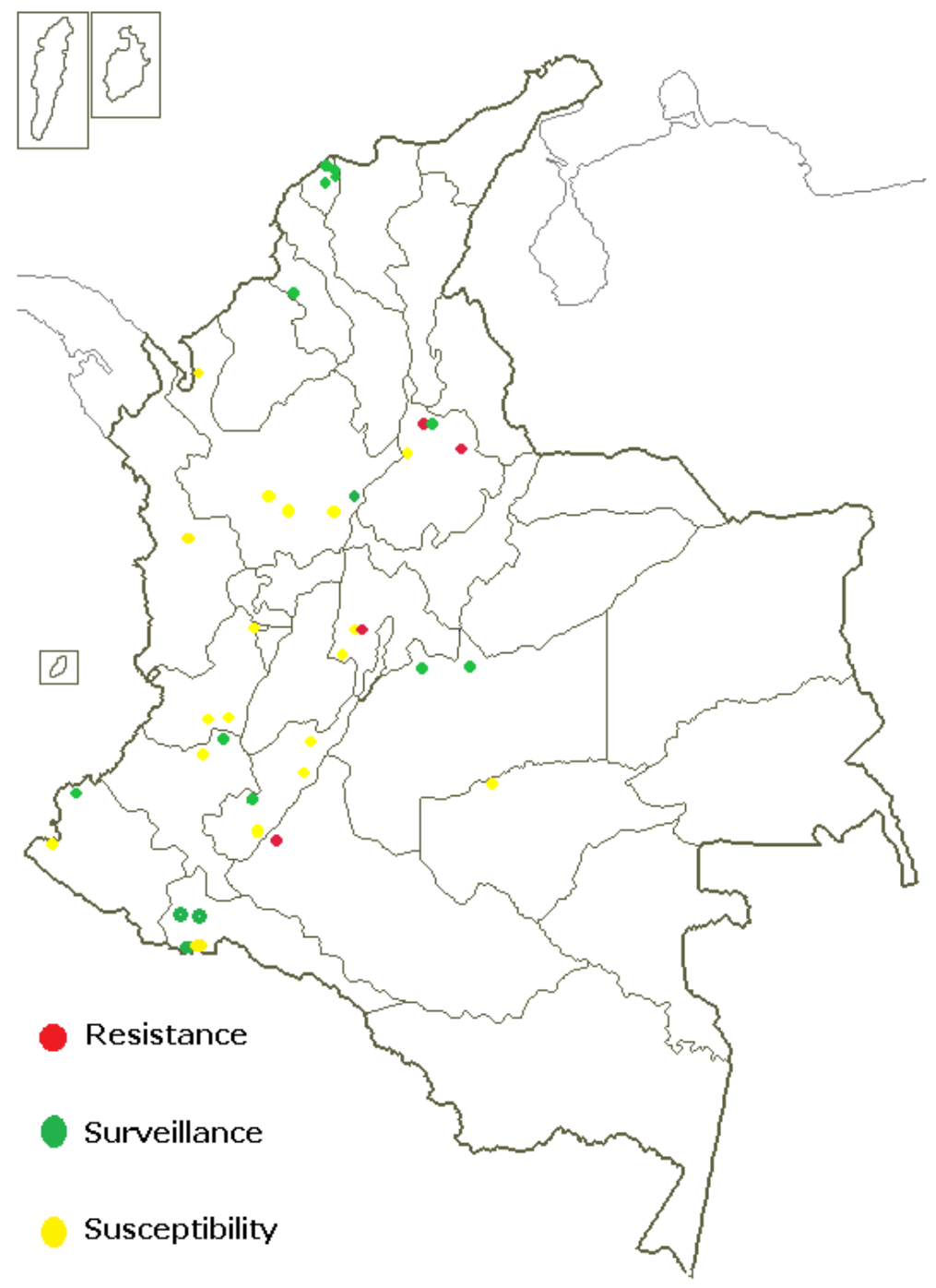

Fig. 7D. Susceptility status of Aedes aegypti populations to Deltamethrin in Colombia (OMS test). 


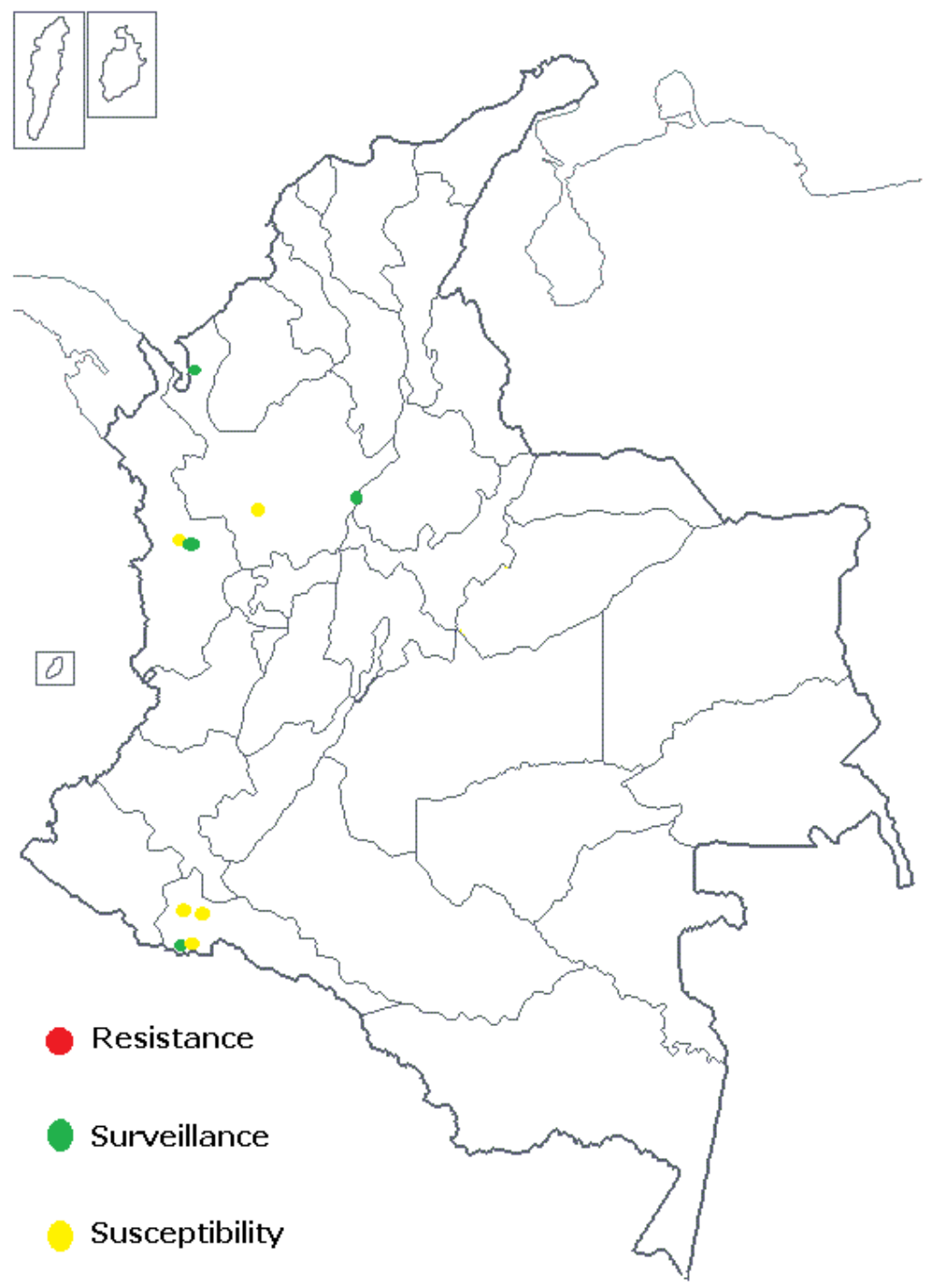

Fig. 7F. Susceptility status of Aedes aegypti populations to cyfluthrin in Colombia (OMS test). 


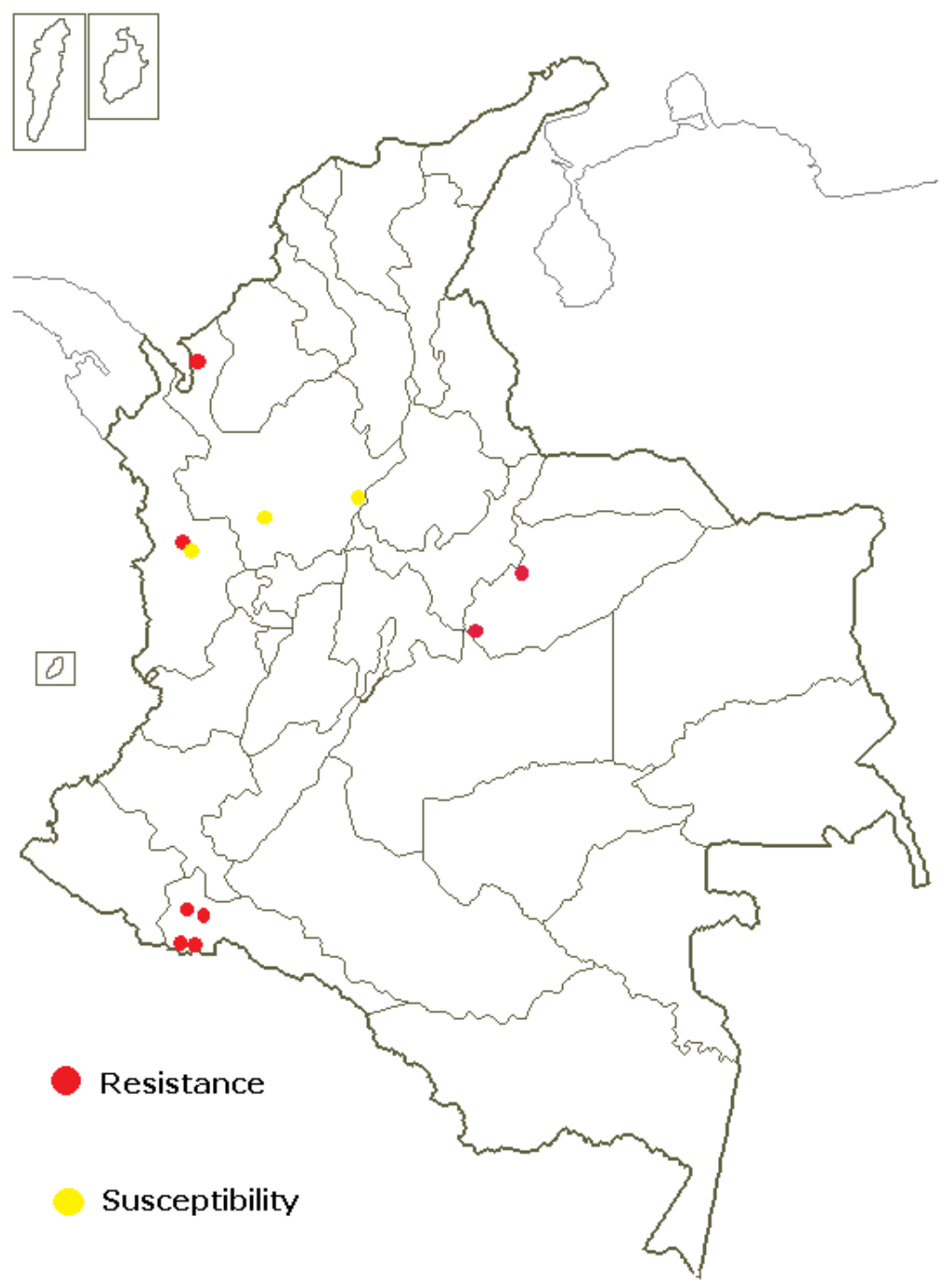

Fig. 7G. Susceptility status of Aedes aegypti populations to Permethrin in Colombia (CDC test). 


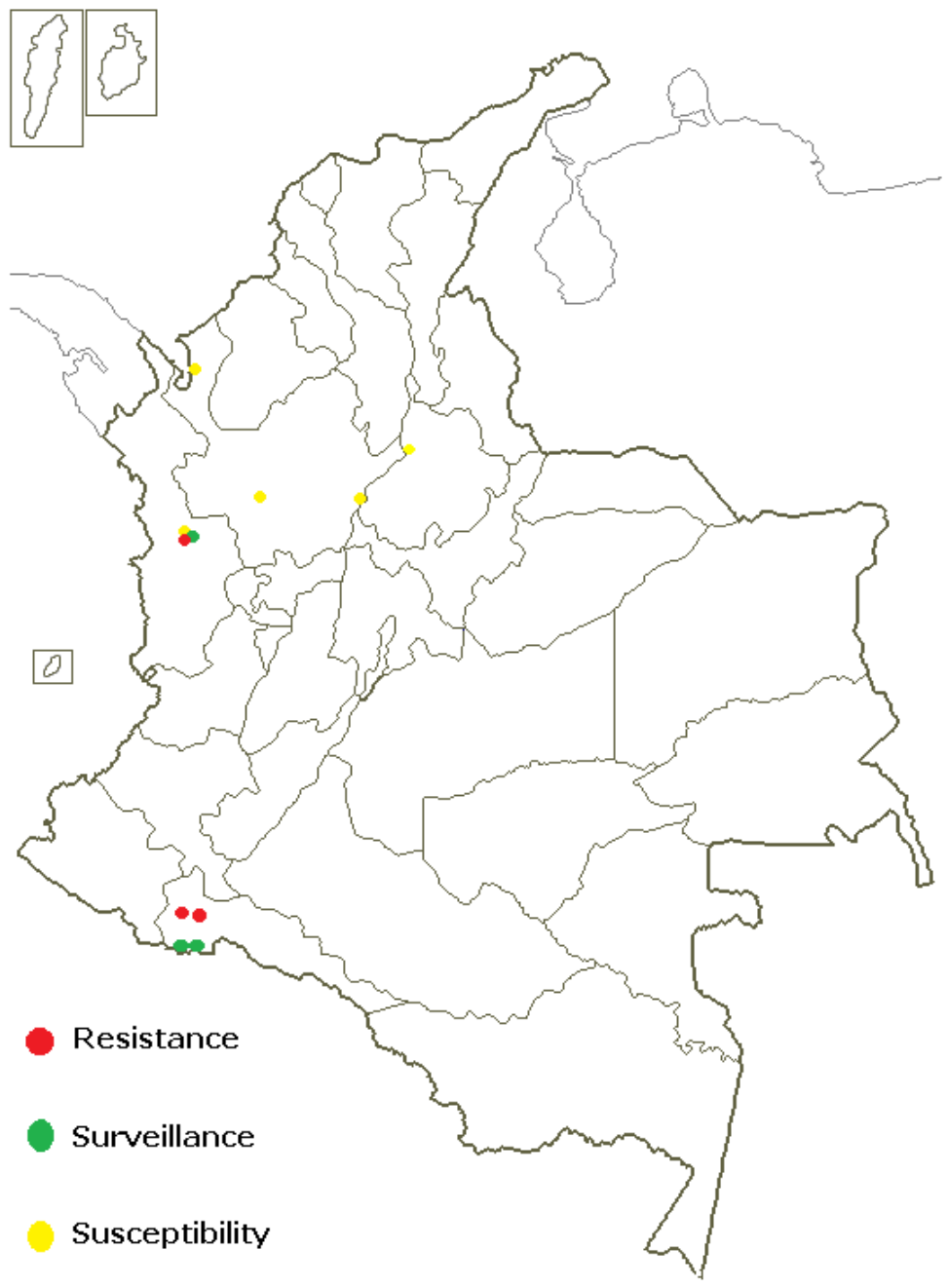

Fig. 7H. Susceptility status of Aedes aegypti populations to Permethrin in Colombia (OMS test). 


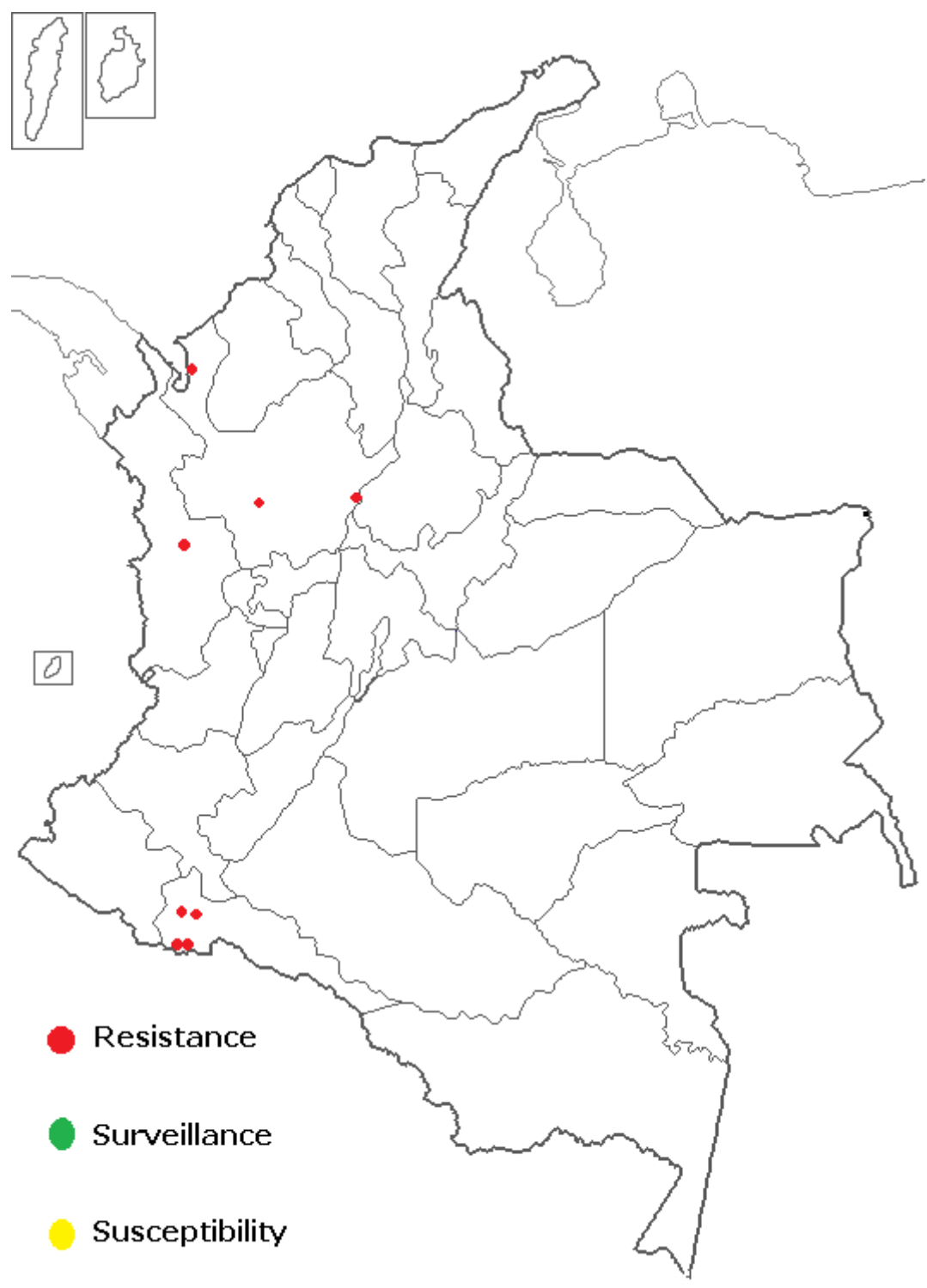

Fig. 7I. Susceptility status of Aedes aegypti populations to etofenprox in Colombia (OMS test). 


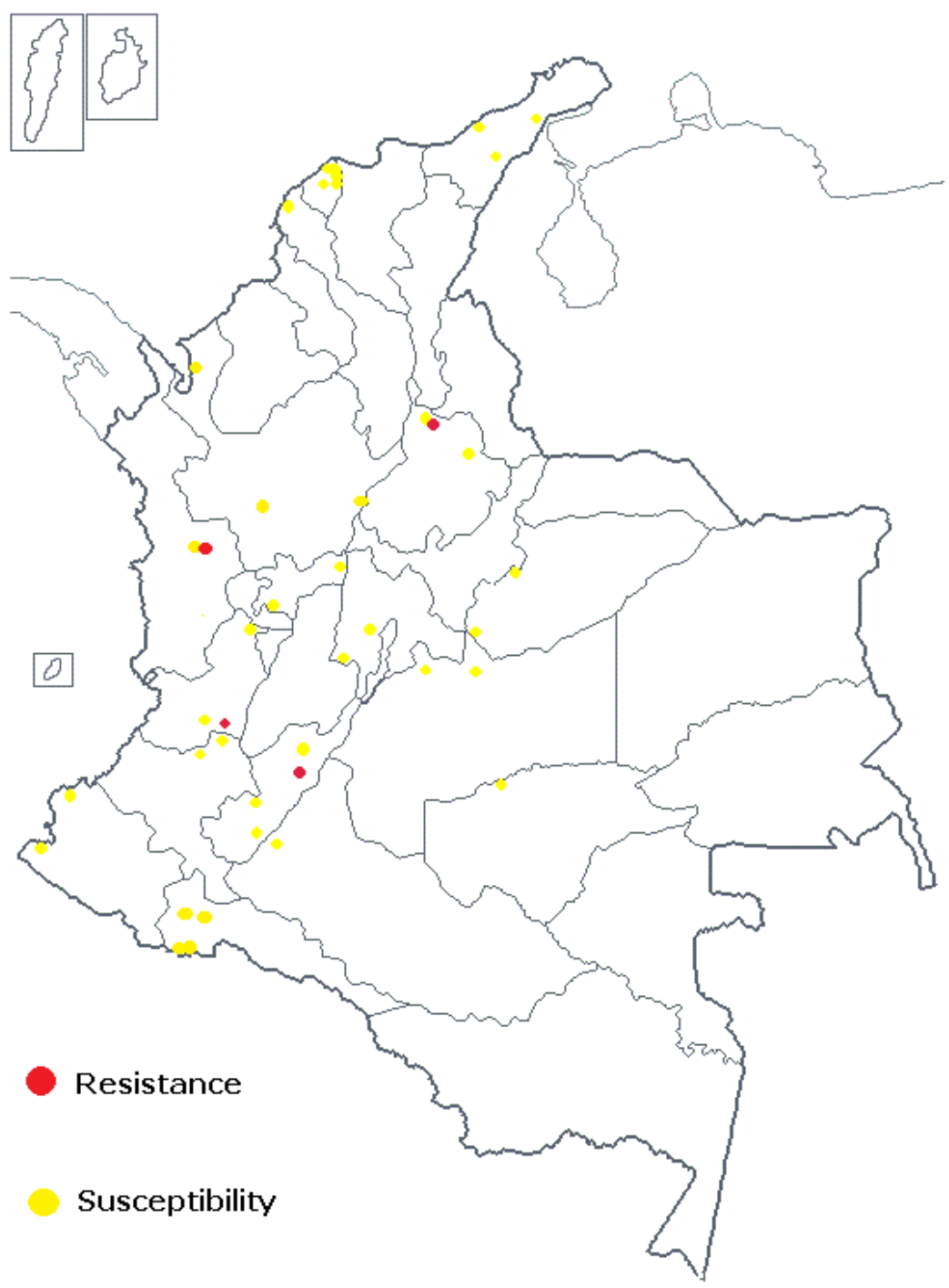

Fig. 8A. Susceptility status of Aedes aegypti populations to Malathion in Colombia (CDC test). 


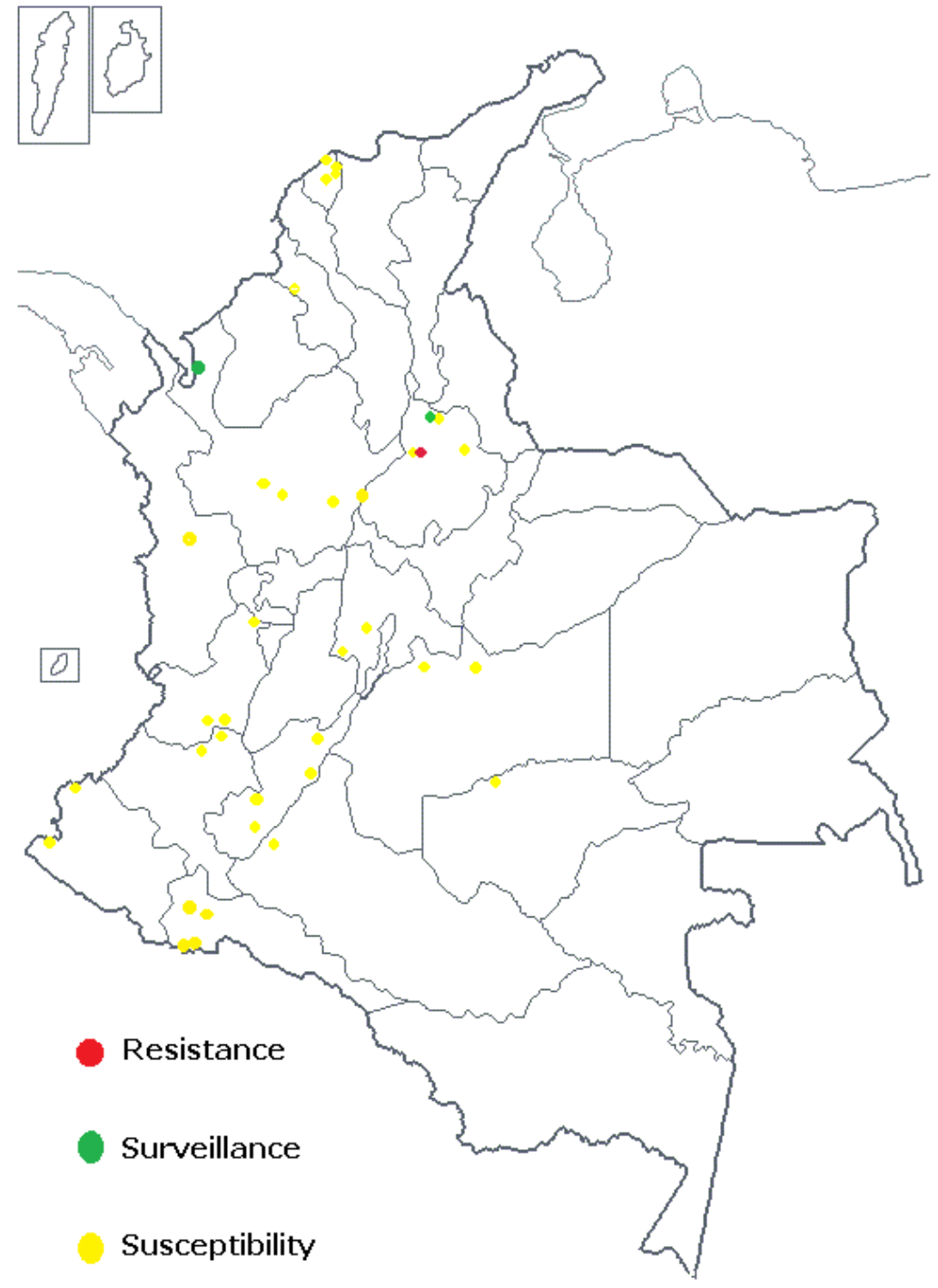

Fig. 8B. Susceptility status of Aedes aegypti populations to Malathion in Colombia (OMS test). 


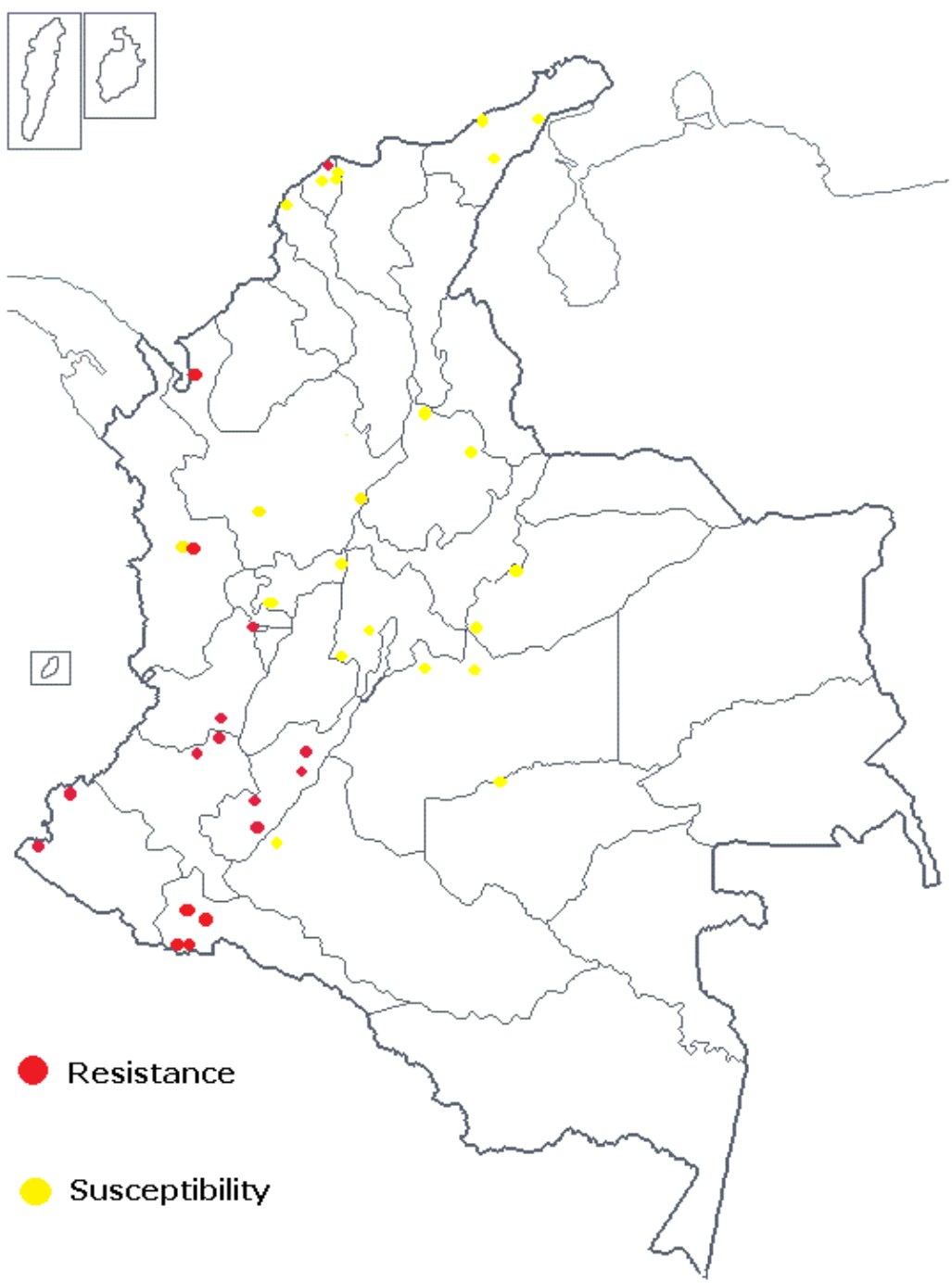

Fig. 8C. Susceptility status of Aedes aegypti populations to Fenitrothion in Colombia (CDC test). 


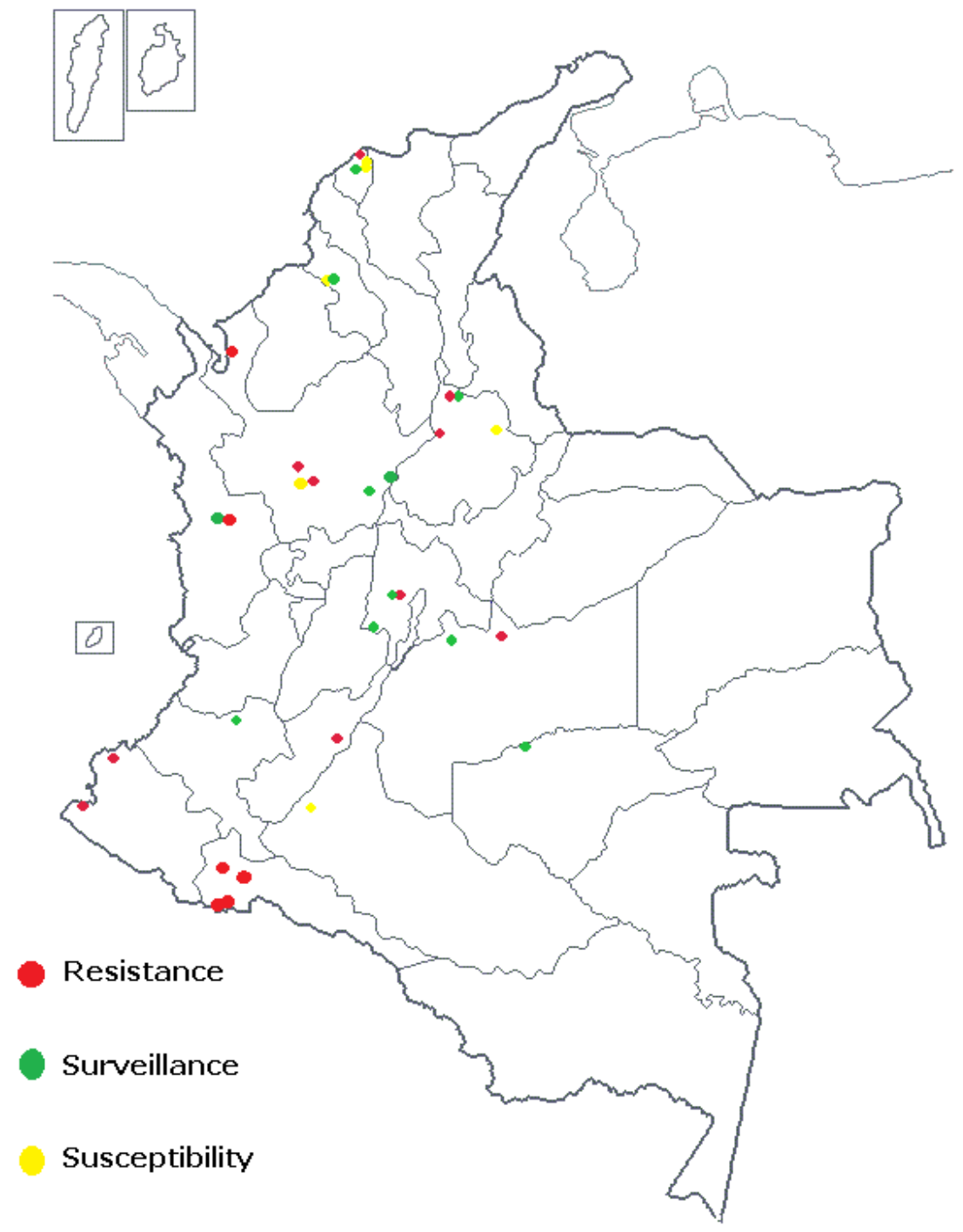

Fig. 8D. Susceptility status of Aedes aegypti populations to Fenitrothion in Colombia (OMS test). 


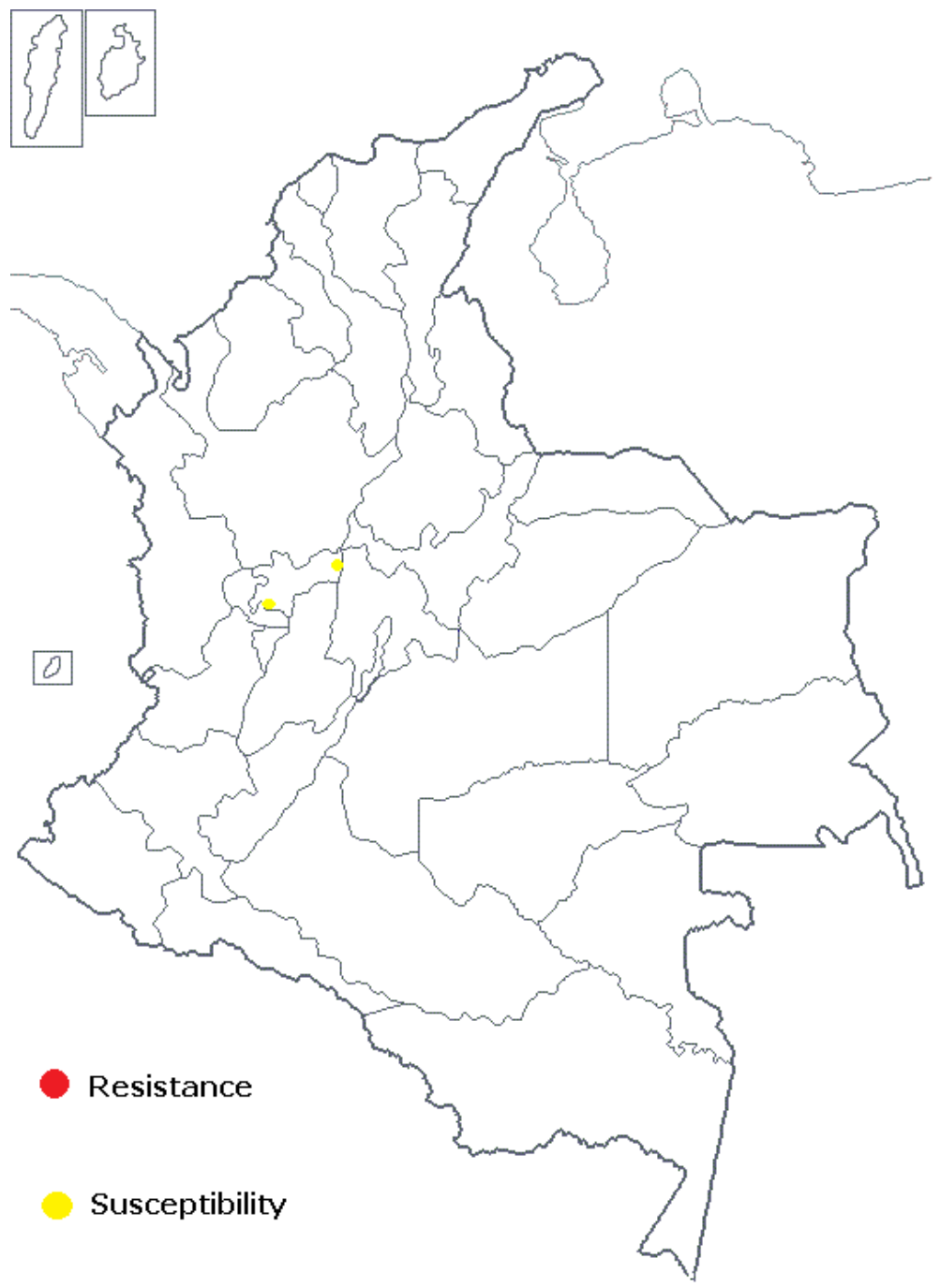

Fig. 8E. Susceptility status of Aedes aegypti populations to pirimiphos methyl in Colombia (CDC test). 


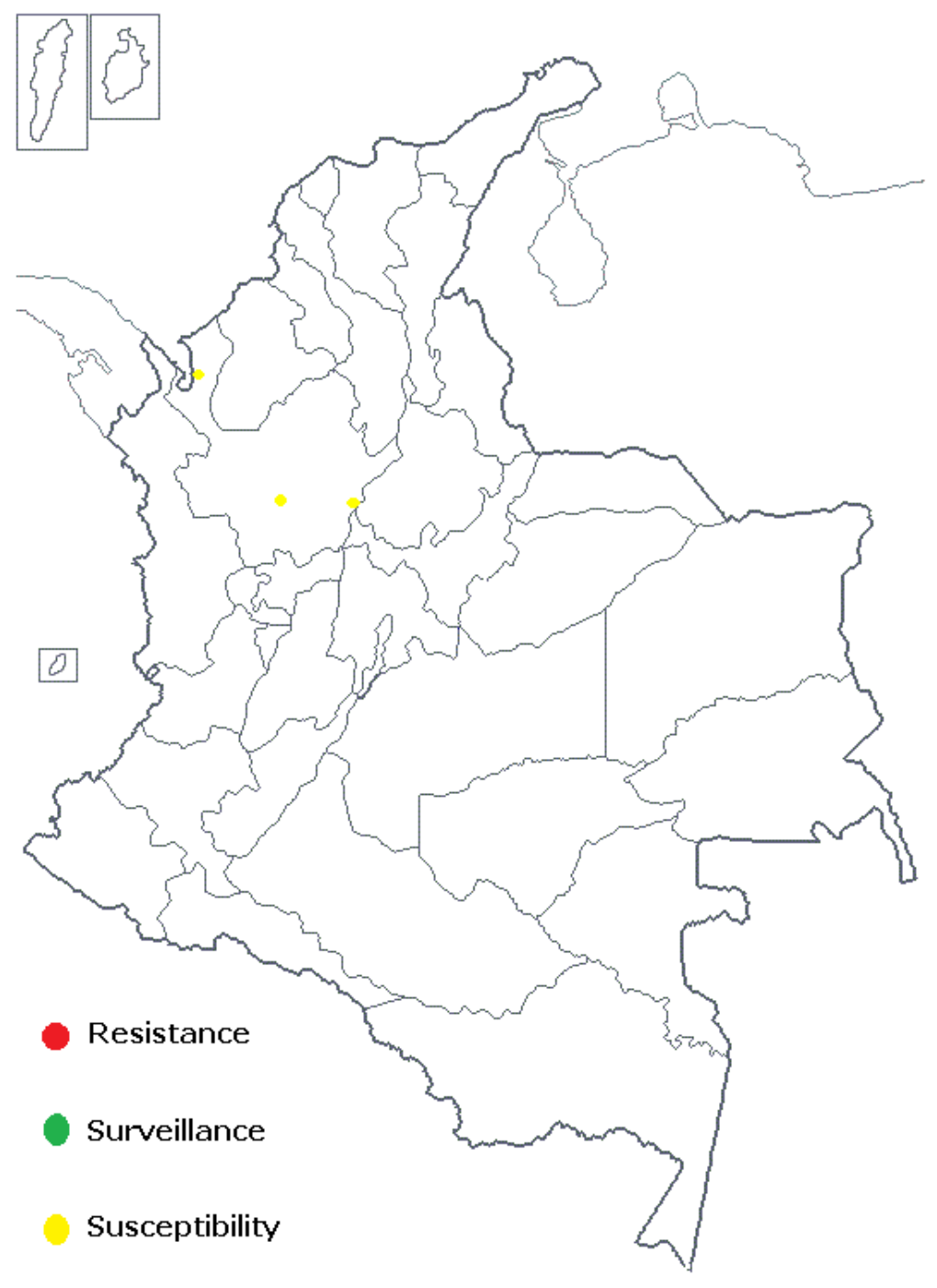

Fig. 8F. Susceptility status of Aedes aegypti populations to pirimiphos methyl in Colombia (OMS test). 


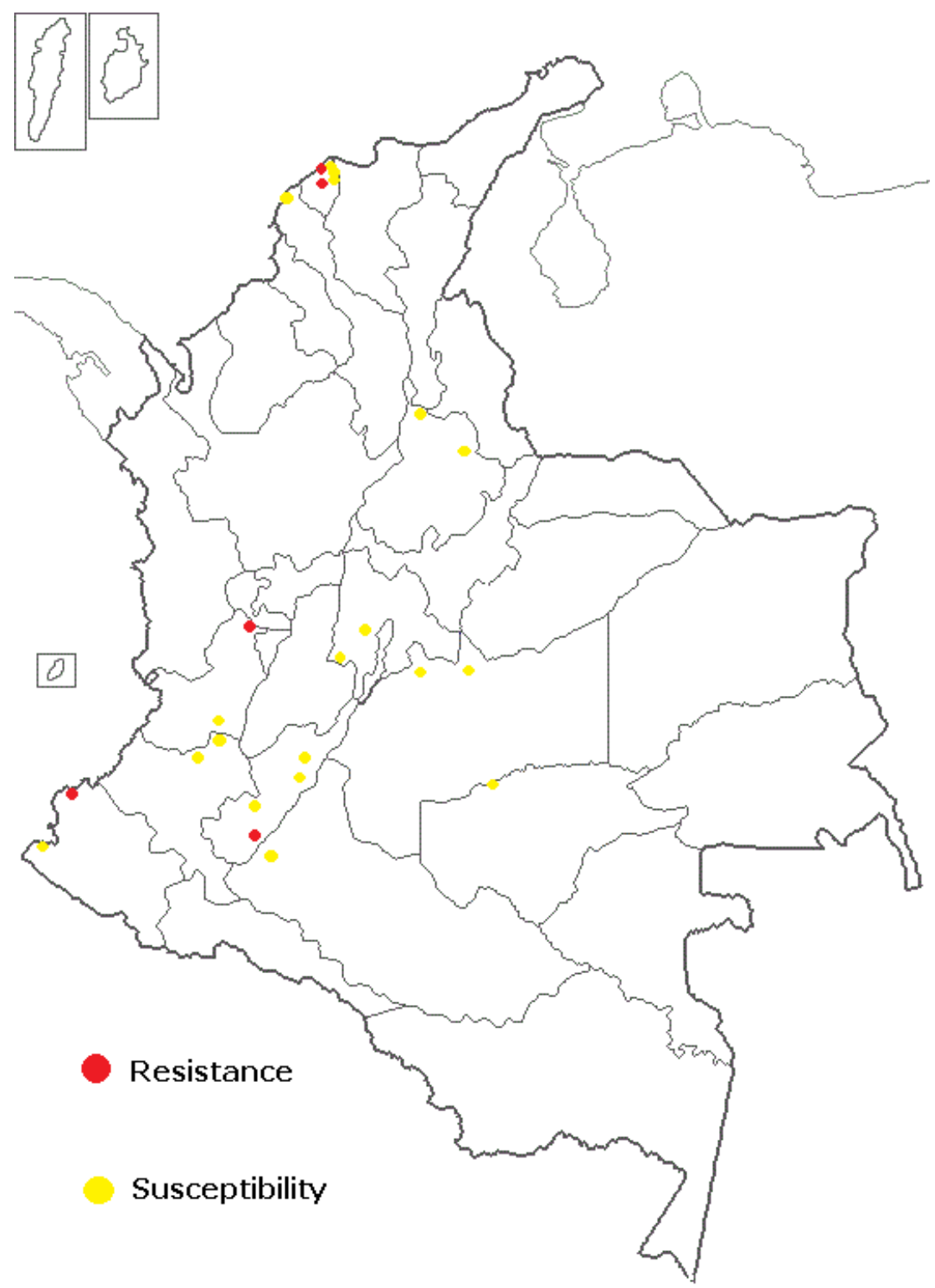

Fig. 9A. Susceptility status of Aedes aegypti populations to propoxur in Colombia (CDC test). 


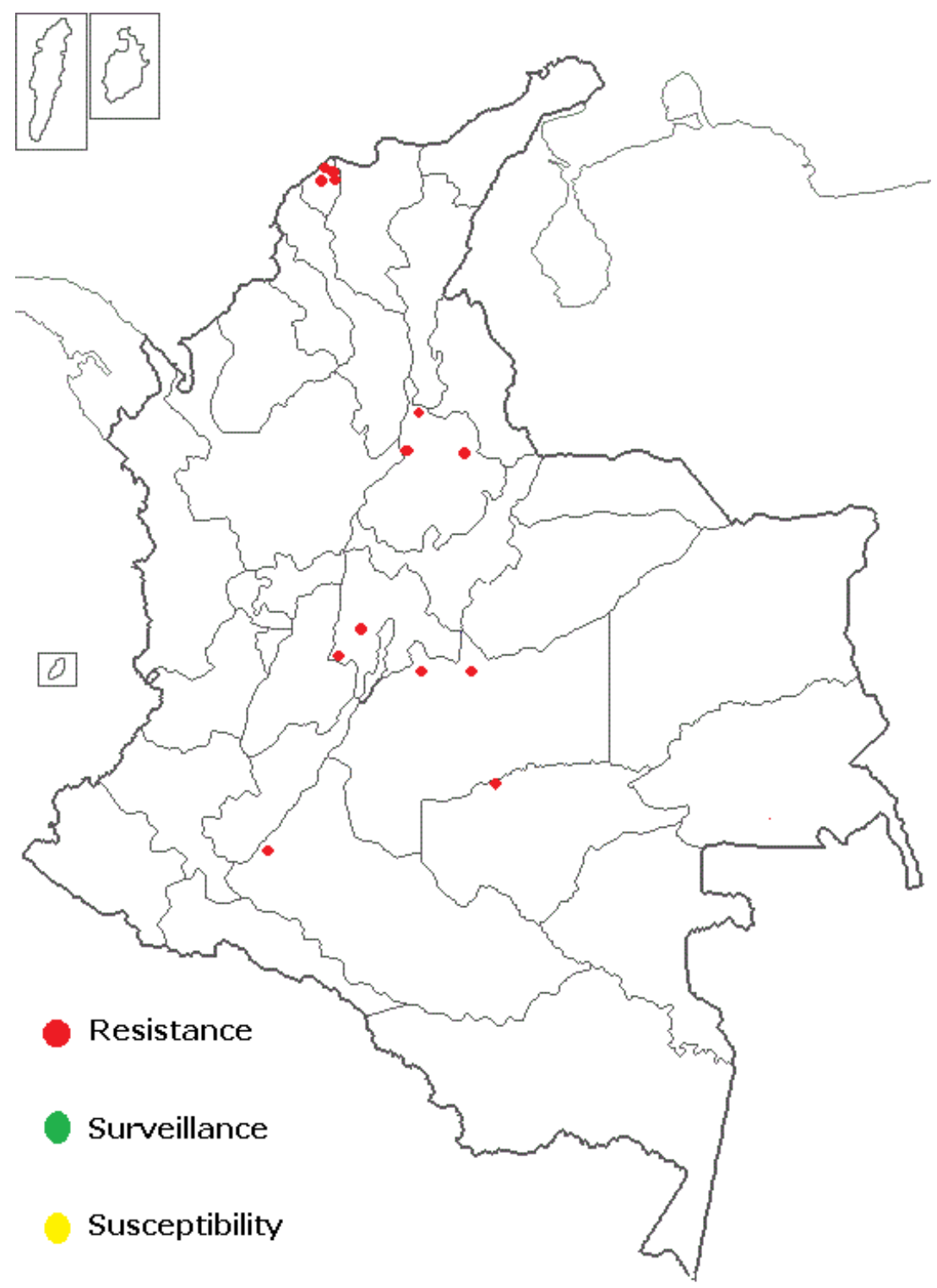

Fig. 9B. Susceptility status of Aedes aegypti populations to propoxur in Colombia (OMS test). 


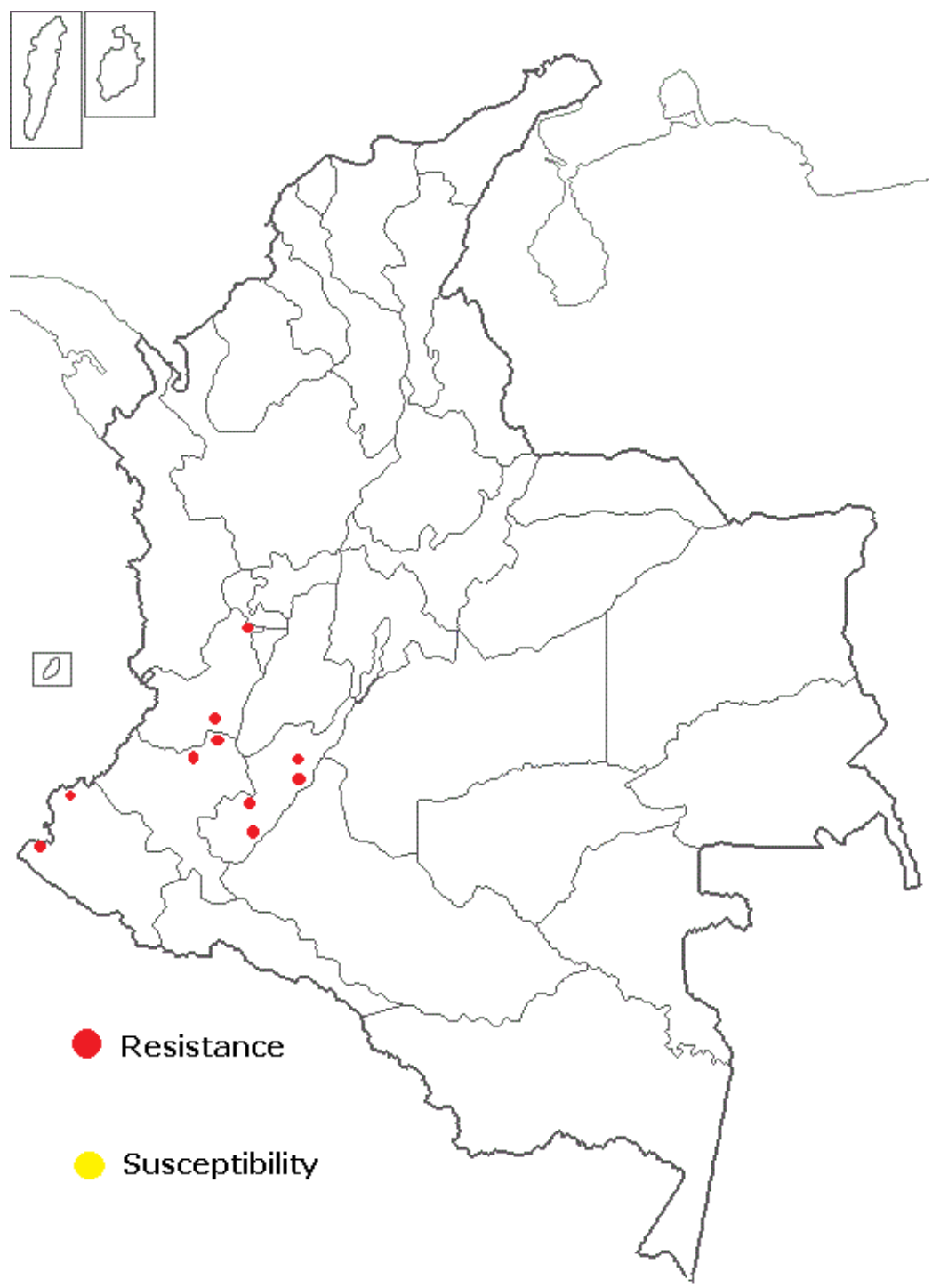

Fig. 10A. Susceptility status of Aedes aegypti populations to bendiocarb in Colombia (CDC test). 


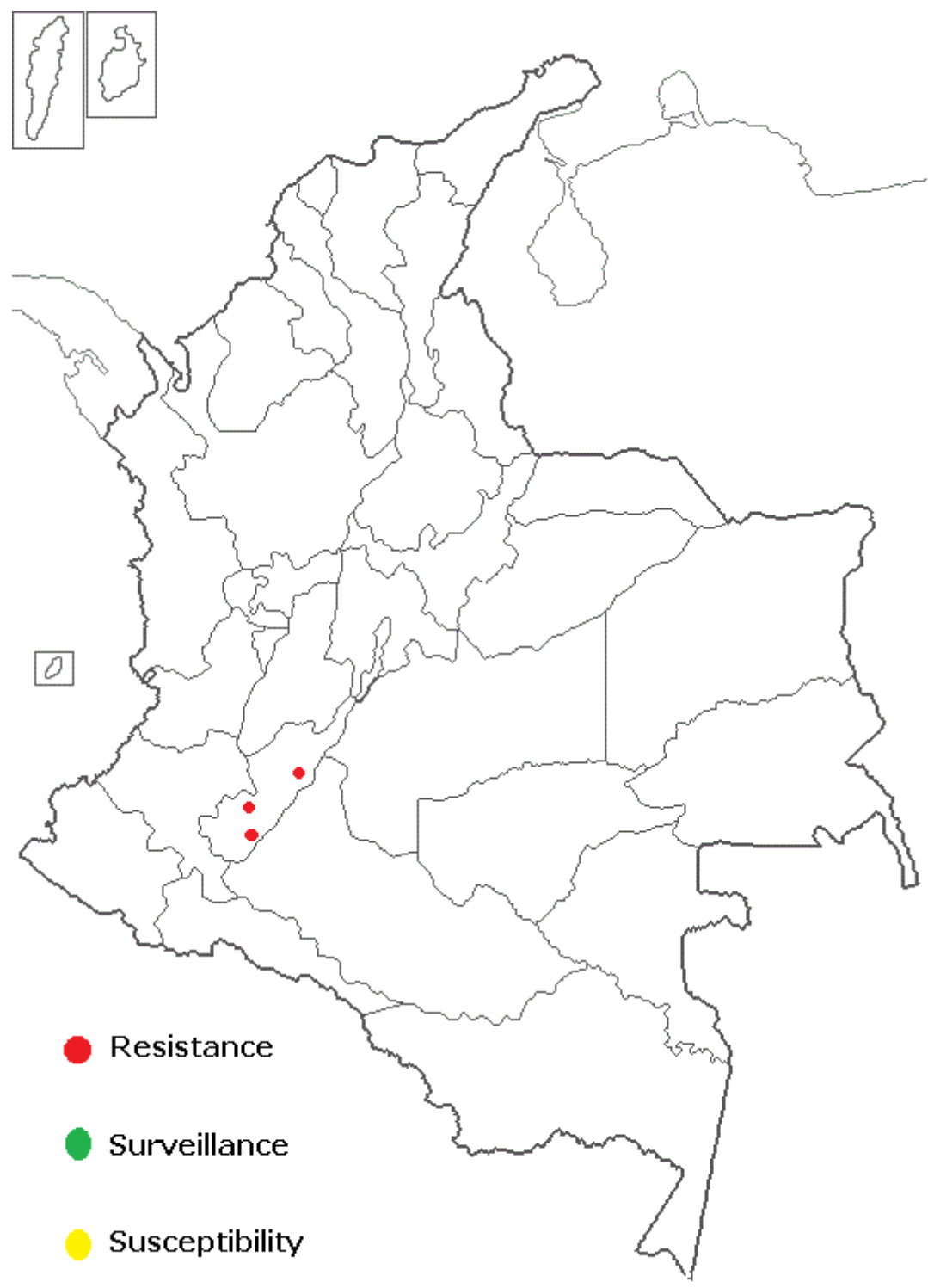

Fig. 10B. Susceptility status of Aedes aegypti populations to bendiocarb in Colombia (OMS test). 


\section{Conclusion}

The selection pressure exert by insecticides for more than five decades on the populations of A. aegypti in Colombia, has generated widespread resistance to DDT and variability in susceptibility to phosphorated, carabamates and pyrethroids insecticides. As a possible cause of metabolic resistance to these insecticides, alteration in nonspecific esterase levels has been registered, mixed function oxidases and s-glutathione transferases. However, it is unknown whether there are alterations in target sites of action, especially in voltagedependent sodium channel genes that explains the generalized resistance to DDT and most pyrethroids in the country.

\section{Acknowledgment}

Sponsored by the project Strengthening UNIMOL Group 2011 Vice-Rectory of Research Res. 4357 (2010) Colombia.

\section{References}

Albrieu-Llinás, G.; Seccacini, E.; Gardenal, CN. \& Licastro, S. (2010). Current resistance status to temephos in Aedes aegypti from different regions of Argentina. Mem Inst Oswaldo Cruz, Vol.105, No.1, pp.113-116.

Álvarez, L.; Briceño, A. \& Oviedo, M. (2006). Resistencia al temefos en poblaciones de Aedes aegypti (Diptera: Culicidae) del occidente de Venezuela. Revista Colombiana de Entomología, Vol.32, No.2, pp.172-5.

Anaya, Y.; Cochero, S.; Rey, G. \& Santacoloma, L. (2007). Evaluación de la Susceptibilidad a insecticidas en Aedes aegypti (Diptera: Culicidae) capturados en Sincelejo. Biomedica, Vol.27, No.2, pp.257-8.

Anstead, JA.; Williamson, MS. \& Denholm, I. (2005). Evidence for multiple origins of identical insecticide resistance mutations in the aphid Myzus persicae. Insect Biochemistry and Molecular Biology, Vol.35, pp.249-256.

Aparecida-Braga, I.; Pereira-Lima, J.; Da Silva-Soares, S. \& Valle, D. (2004). Aedes aegypti resistance to temephos during 2001 in several municipalities in the states of Rio de Janeiro, Sergipe and Alagoas, Brazil. Memórias do InstitutoOswaldo Cruz, Vol.99, No.2, pp.199-203.

Ardila-Roldan, S. \& Brochero, HL. (2010).Status of insecticide resistance in natural population from Aedes aegypti and CAP surveys of dengue vector in Casanare, Colombia. Journal of American Mosquito Control Association, Vol.26, No.3, pp.306-20.

Beserra, E.; Fernández, C.; De Quiroga, M. \& De Castro, F. (2007). Resistance of Aedes aegypti (L.) (Diptera: Culicidae)populations to organophosphates temephos in the Paraíba State, Brazil. Neotropical Entomology, Vol.36, No.2, pp.303-7.

Bisset, JA.; Rodríguez, MM.; Molina, D.; Díaz, C. \& Soca, LA. (2001). Esterasas elevadas como mecanismo de resistencia a insecticidas organofosforados en cepas de Aedes aegypti. Revista Cubana de Medicina Tropical, Vol.53, No.1, pp.37-43.

Bisset J. (2002).Uso correcto de insecticidas: control de la resistencia. Revista Cubana de Medicina Tropical, Vol.54, No.3, pp.202-219. 
Bisset-Lazcano JA.; Rodríguez, MM.; San Martín, JL.; Romero, JE. \& Montoya, R. (2009).Evaluación de la resistencia a insecticidas de una cepa de Aedes aegypti de El Salvador. Revista Panamericana de Salud Publica, Vol.26, No.3, pp.229-34.

Brogdon, W. \& Mcallister, J. (1998).Simplification of adult mosquito bioassays through use of time mortality determinations in glass bottles. Journal of the American Mosquito Control Association, Vol.14, No2, pp.159-64.

Brengues, C.; Hawkes, NJ.; Chandre, F.; McCarroll, L.; Duchon, S. \& Guillet, P. et al. (2003). Pyrethroid and DDT cross-resistance in Aedes aegypti is correlated with novel mutations in the voltagegated sodium channel gene. Med Vet Entomol., Vol.17, pp.87-94.

Brooke B. (2008). kdr: can a single mutation produce an entire insecticide resistance phenotype?. Transactions of the Royal Society of Tropical Medicine and Hygiene, Vol.102, pp.524-525.

Brown, A. (1986). Insecticide resistance in mosquitoes: a pragmatic review. Journal of American Mosquito Control Association, Vol.2, pp.123-40.

Cadavid, JM.; Valderrama-Hernández, R.; Saenz-Osorio, O.; Quintero-Ruiz, B.; Rodríguez Ríos, C. \& Contreras-Samper, A. (2008). Susceptibility of Aedes aegypti to insecticides in three high dengue transmission localities of Antioquia, Colombia Journal of American Mosquito Control Association, Vol.22, No.4, pp.748.

Chang, Ch.; Shen, WK.; Wang, TT.; Lin, YH.; Hsu, EL. \& Dai, SM. (2009). A novel amino acid substitution in a voltage-gated sodium channel is associated with knockdown resistance to permethrin in Aedes aegypti. Insect Biochemistry and Molecular Biology, Vol.39, pp. 272-278

Chávez, J.; Vargas, J. \& Vargas, F. (2005). Resistencia a deltametrina en dos poblaciones de Aedes aegypti (Diptera: Culicidae) del Perú. Revista Peruana de Biología, Vol.12, No1, pp.161-4.

Cui, F.; Weill, M.; Berthomieu, A.; Raymond, M. \& Qiao, Ch. (2007). Characterization of novel esterases in insecticide-resistant mosquitoes. Insect Biochemistry and Molecular Biology,Vol.37, pp.1131-37.

Escobar JP. (2009). Políticas y orientaciones técnicas OPS/OMS para prevención y control del dengue y dengue hemorrágico. Biomédica, Vol.29, No1, pp.123-5.

Feyereisen R. (1999). Insect P450 enzymes. Annu. Rev. Entomol., Vol.44, pp.507-33.

Flores, A.; Albeldaño-Vásquez, W.; Fernández-Salas, I.; Badii, M.; Loaiza-Becerra, H.;

Ponce-Garcia, G.; Lozano-Fuentes, S.; Brogdon, W.; Black, W.; Beaty, B. (2005). Elevated áesterase levels associated withpermethrin tolerance in Aedes aegypti (L.) from Baja California, México. Pesticide Biochemistry and Physiology, Vol.82, pp.66-78.

Fonseca, I. \& Quiñones, M. (2005). Resistencia a insecticidas en mosquitos (Diptera: Culicidae): Mecanismos, detección y vigilancia en salud pública. Revista Colombiana de Entomología, Vol.31, No2, pp.107-115.

Fonseca I., Brant T.,Quiñones ML., Brogdonm, WG. (2006). Increased glutathione S transferases associated to DDT resistance in Aedes aegypti from Colombia. Journal of American Mosquito Control Association, Vol.22, No4, pp.738.

Fonseca, I.; Bolaños, D.; Gomez, W. \& Quiñones, ML. (2007). Evaluación de la susceptibilidad de larvas de Aedes aegypti a insecticidas en el deprtamento del Antioquia. Biomedica, Vol.27, No.2, pp.176-7. 
Fonseca-González, I. (2008). Estatus de la resistencia a insecticidas de los vectores primarios de malaria y dengue en Antioquia, Chocó, Norte de Santander y Putumayo, Colombia. [Tesis de doctorado]. Medellín: Universidad de Antioquia.

Fonseca, I. \& Bolaños, D. (2009).Variación temporal en la susceptibilidad a malatión y Lambdacialotrina en Aedes aegypti (L) de Quibdo, Colombia. Biomédica, Vol.29, No.1, pp.218-9.

Fonseca-Gonzalez, I.; Quiñones, ML.; Lenhartc, A. \& Brogdon, WG. (2011). Insecticide resistance status of Aedes aegypti (L.) from Colombia. Pest Management Science, Vol.67, No.4, pp.430-7.

Gómez-Camargo DE.; Maestre, RY.; Pisciotti, I.; Malambo, DI. \& Gómez-Alegría, CJ. (2010). Insecticide susceptibility of Aedes aegypti in Cartagena (Colombia). The American Journal of Tropical Medicine and Hygiene, Vol.83, No.5, pp.298-9.

Hemingway, J. \& Black IV, WC. (2007). A mutation in the voltage-gated sodium channel gene associated with pyrethroid resistance in Latin American Aedes aegypti. Insect Molecular Biology, Vol.16, No.6, pp.785-98.

Lumjuan, N.; Stevensona, BJ.; Prapanthadarab, L.; Somboonc, P.; Brophyd, PM.; Loftuse, BJ.; Seversonf, DW. \& Ransona, H. (2007). The Aedes aegypti glutathione transferase family. Insect Biochemistry and Molecular Biology, Vol.37, pp.1026-35.

Macoris, M.; Andrighetti, M.; Takaku, L.; Glasse, C.; Garbeloto, V. \& Bracco, J. (2003). Resistance of Aedes aegypti from the state of Sao Paulo, Brazil to Organophosphates insecticidas. Memórias do Instituto Oswaldo Cruz, Vol.98, No.5, pp.703-8.

Maestre, R.; Rey, G.; De las Salas, J.; Vergara, C.; Santacoloma, L.; Goenaga, S. \& Carrasquilla, MC. (2009). Susceptibilidad de Aedes aegypti (Diptera: Culicidae) a temefos en Atlántico-Colombia. Revista Colombiana de Entomología, Vol.35, No.2, pp.202-205.

Maestre-Serrano, R.; Goenaga, S.; Carrasquilla-Ferro MC.; Rey-Vega G.; Santacoloma-Baron L. \& Vergara-Sánchez C. (2009). Estado de la susceptibilidad/resistencia a insecticidas en cuatro poblaciones de Aedes aegypti del departamento del Atlántico. Biomedica, Vol.29, No.1, pp.231-2.

Maestre, RY.; Florez, Z.; Cabrera, C.; Goenaga, S.; Gómez, D. \& Gómez, C. (2010). Susceptibility status of Aedes aegypti to insecticides in La Guajira (Colombia). The American Journal of Tropical Medicine and Hygiene, Vol.83, No.5, pp.53.

Maestre, R.; Rey, G.; De las Salas, J.; Vergara, C.; Santacoloma, L.; Goenaga, S. \& Carrasquilla, MC. (2010). Estado de la susceptibilidad de Aedes aegypti a insecticidas en Atlántico (Colombia). Revista Colombiana de Entomología,Vol.36, No.2, pp.242-248.

Maestre-Serrano, R.; Goenaga, S.; Flores, Z.; Cabrera C.; Gómez, D. \& Gómez, C. (2010). The Amercican Journal of Tropical Medicine and Hygiene Vol.83, No.5, pp.53.

Martins, AJ.; Pereira-Lima, JB.; Peixoto, AA. \& Valle, D. (2009). Frequency of Val1016Ile mutation in the voltage-gated sodium channel gene of Aedes aegypti Brazilian populations. Tropical Medicine and International Health, Vol.14, No.11, pp.1351-55.

Martinez-Torres, D.; Chandre, F.; Williamson, MS.; Darriet, F.; Berge, JB.; Devonshire, AL.; Guillet, P.; Pasteur, N. \& Pauron, D. (1998). Molecular characterization of pyrethroid knockdown resistance $(\mathrm{kdr})$ in the major malaria vector Anopheles gambiae s.s. Insect Molecular Biology, Vol.7, pp.179-184.

Miller TA. 1988. Mechanisms of resistance to pyrethroid insecticides. Parasitology Today, Vol.4, pp.8-12. 
Ocampo, C.; Salazar-Terreros, M.; Mina, N.; McAllister, J. \& Brogdon, W. (2011). Insecticide Resistance status of Aedes aegypti in 10 localities of Colombia. Acta Trop., Vol.118 No.1, pp.37-44.

Orjuela, L.; Herrera, M.; Quintana, N. \& Quiñones, M. (2007). Estado de la susceptibilidad a insecticidas del mosquito Aedes aegypti en lo municipios de Chinchiná y La Dorada, Caldas. Biomedica, Vol.27, No.2, pp.176.

Pereira-da-Cunha, M.; Pereira-Lima JB.; Brogdon, WG.; Efrain-Moya G. \& Valle D. (2005). Monitoring of resistance to the pyrethroid cypermethrin in Brazilian Aedes aegypti (Diptera: Culicidae) populations collected between 2001 and 2003. Memorias do Instituto Oswaldo Cruz, Vol.100, No.4, pp.441-44.

Pereira-Lima, E.; Da Oliveira-Filho, A.; Da Oliveira-Lima, J.; Ramos-Junior, A.; Da GoesCavalcanti, L. \& Soares-Pontes, R. (2006). Aedes aegypti resistance to temephos in counties of Ceará State. Revista da Sociedade Brasileira de Medicina Tropical, Vol.39, No.3, pp.259-63.

Polson, KA.; Rawlins, SC.; Brogdon, WG. \& Chadee, DD. (2010). Biochemical mechanisms involved in DDT and pyrethroid resistance in Trinidad and Tobago strains of Aedes aegypti. The American Journal of tropical medicine and hygiene, Vol.83, No.5, pp.51.

Poupardin, R.; Reynaud, S.; Strode, C.; Ranson, H.; Vontas, J. \& David JP. (2008). Crossinduction of detoxification genes by environmental xenobiotics and insecticides in the mosquito Aedes aegypti: Impact on larval tolerance to chemical insecticides. Insect Biochemistry and Molecular Biology, Vol.38, pp.540-51.

Quiñones, ML.; Suarez, MF. \& Fleming, GA. (1987). Estado de la susceptibilidad al DDT de los principales vectores de malaria en Colombia y su implicación epidemiológica. Biomédica, Vol.7, pp.81-6.

Rawlins S. (1998). Distribución espacial e importancia de la resistencia a insecticidas de poblaciones de Aedes aegypti en el Caribe. Revista Panamericana de Salud Pública, Vol.4, No.4, pp.243-51.

Rodríguez, M.; Bisset, J.; Fernández, D. \& Pérez, O. (2004). Resistencia a insecticidas en larvas y adultos de Aedes aegypti: prevalencia de esterasa A4 asociada con la resistencia a temefos. Revista Cubana de Medicina Tropical, Vol.56, No.1, pp.54-60.

Rodríguez, MM.; Bisset, JA. \& Fernández, D. (2007). Determinación in vivo del papel de las enzimas esterasas y glutation transferasa en la resistencia a piretroides en Aedes aegypti (Diptera: Culicidae). Revista Cubana de Medicina Tropical, Vol.59, No.3, pp.209-12.

Rodríguez, M. (2008). Estudio de la resistencia a insecticidas en Aedes aegypti (Diptera: Culicidae). Tesis presentada al grado científico de Doctor en Ciencias de la Salud. Laboratorio de Toxicología y genética. Instituto de Medicina Tropical "Pedro Kourí". 128p.

Rojas, W.; Gonzalez, J.; Amud, MI.; Quiñones, ML. \& Velez, ID. (2003). Evaluación de la susceptibilidad de Aedes aegypti del municipio de Barrancabermeja Santander a los insecticidas Malatión Fenitrotion, temefos, Lambdacihalotrina, deltametrina, permetrina, propoxur y DDT. Biomédica, Vol.23, No.1, pp.56

Rojas-Alvarez, DP. (2010). Comportamineto epidemiologico del dengue en Colombia, año 2009. Informe quincenal Epidemiologico Nacional, Vol.15, No.9, pp.129-37.

Saavedra-Rodriguez, K.; Urdaneta-Marquez, L.; Rajatileka, S.; Moulton, M.; Flores, AE.; Fernandez-Salas, I.; Bisset, J.; Rodriguez, M.; Mccall, PJ.; Donnelly, MJ.; Ranson, H.; 
Salazar, M.; Carvajal, A.; Cuellar, ME.; Olaya, A.; Quiñones, J.; Velásquez, OL.; Viveros, A. \& Ocampo, C. (2007). Resitencia a insecticidas en poblaciones de Aedes aegypti y Anopheles spp en los departamentos de Huila, valle Cauca y Nariño. Biomédica, Vol.27, No.2, pp.177.

Santacoloma, L. (2008). Estado de la susceptibilidad a insecticidas de poblaciones naturales de Aedes aegypti Linnaeus 1762 vector del dengue y Anopheles darlingi root 1926 vector primario de malaria (Diptera: Culicidae) en cinco departamentos de Colombia. [Tesis de maestría]. Bogotá: Universidad Nacional de Colombia.

Santacoloma-Varon, L.; Chavez-Cordoba, B. \& Brochero, HL. (2010). Susceptibilidad de Aedes aegypti a DDT, Deltametrina y Lambdacialotrina en Colombia. Revista Panamericana de Salud Publica, Vol.27, No.1, pp.66-73.

http://www.todacolombia.com/geografia/ubicacion.html

Valderrama-Eslava, EI.; Gomzalez, R. \& Jaramillo, GI. (2008). Evaluación de la susceptibilidad de Aedes aegypti (L) (Diptera: Culicidae) a un insecticida Organosfosforado y un piretroide en cuatro poblaciones del Valle del Cauca, mediante dos tipos de bioensayos. Boletin del Museo de Entomología de la Universidad del Valle, Vol.9, No.2, pp.1-11.

World Health Organization (WHO). (1957). Seventh report Expert Committee on insecticides WHO Tech Report Ser, Vol.125, pp.37.

World Health Organization (WHO). (1981a). Instructions for determining the susceptibility or resistance of adult mosquitoes to organoclorine, organophosphorus and carbamate insecticides. Establishment of the base-line. WHO/ VBC/81.805.

World Health Organization (WHO). (1981b). Instructions for determining the susceptibility or resistance of mosquitoes larvae to insecticide. Unpublished document.WHO/ $\mathrm{VBC} / 81.807$.

Yanola, J.; Somboon, P.; Walton, C.; Nachaiwieng, W. \& Prapanthadara L. (2010). A novel F1552/C1552 point mutation in the Aedes aegypti voltage-gated sodium channel gene associated with permethrin resistance. Pesticide Biochemistry and hysiology, Vol.96, pp.127-13. 


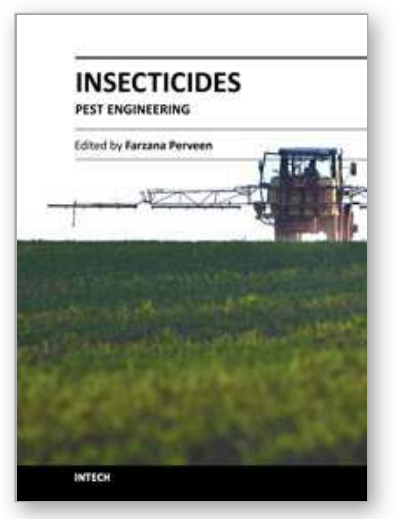

\author{
Insecticides - Pest Engineering \\ Edited by Dr. Farzana Perveen
}

ISBN 978-953-307-895-3

Hard cover, 538 pages

Publisher InTech

Published online 15, February, 2012

Published in print edition February, 2012

This book is compiled of 24 Chapters divided into 4 Sections. Section A focuses on toxicity of organic and inorganic insecticides, organophosphorus insecticides, toxicity of fenitrothion and permethrin, and dichlorodiphenyltrichloroethane (DDT). Section B is dedicated to vector control using insecticides, biological control of mosquito larvae by Bacillus thuringiensis, metabolism of pyrethroids by mosquito cytochrome P40 susceptibility status of Aedes aegypti, etc. Section $C$ describes bioactive natural products from sapindacea, management of potato pests, flower thrips, mango mealy bug, pear psylla, grapes pests, small fruit production, boll weevil and tsetse fly using insecticides. Section $D$ provides information on insecticide resistance in natural population of malaria vector, role of Anopheles gambiae P450 cytochrome, genetic toxicological profile of carbofuran and pirimicarp carbamic insecticides, etc. The subject matter in this book should attract the reader's concern to support rational decisions regarding the use of pesticides.

\title{
How to reference
}

In order to correctly reference this scholarly work, feel free to copy and paste the following:

Ronald Maestre Serrano (2012). Susceptibility Status of Aedes aegypti to Insecticides in Colombia, Insecticides - Pest Engineering, Dr. Farzana Perveen (Ed.), ISBN: 978-953-307-895-3, InTech, Available from: http://www.intechopen.com/books/insecticides-pest-engineering/susceptibility-status-of-aedes-aegypti-toinsecticides-in-colombia

\section{INTECH}

open science | open minds

\section{InTech Europe}

University Campus STeP Ri

Slavka Krautzeka 83/A

51000 Rijeka, Croatia

Phone: +385 (51) 770447

Fax: +385 (51) 686166

www.intechopen.com

\section{InTech China}

Unit 405, Office Block, Hotel Equatorial Shanghai

No.65, Yan An Road (West), Shanghai, 200040, China

中国上海市延安西路65号上海国际贵都大饭店办公楼 405 单元

Phone: +86-21-62489820

Fax: $+86-21-62489821$ 
(C) 2012 The Author(s). Licensee IntechOpen. This is an open access article distributed under the terms of the Creative Commons Attribution 3.0 License, which permits unrestricted use, distribution, and reproduction in any medium, provided the original work is properly cited. 